\title{
Chronology of Lake El'gygytgyn sediments - a combined magnetostratigraphic, palaeoclimatic and orbital tuning study based on multi-parameter analyses
}

\author{
N. R. Nowaczyk ${ }^{1}$, E. M. Haltia ${ }^{1,{ }^{*}}$, D. Ulbricht ${ }^{1,{ }^{* *}}$, V. Wennrich ${ }^{2}$, M. A. Sauerbrey ${ }^{2}$, P. Rosén ${ }^{3}$, H. Vogel ${ }^{2, * * *}$, \\ A. Francke ${ }^{2}$, C. Meyer-Jacob ${ }^{2, * * *}$, A. A. Andreev ${ }^{2}$, and A. V. Lozhkin ${ }^{4}$ \\ ${ }^{1}$ Helmholtz Centre Potsdam, GFZ German Research Centre for Geosciences, Section 5.2 - Climate Dynamics and Landscape \\ Evolution, Telegrafenberg, 14473 Potsdam, Germany \\ ${ }^{2}$ University of Cologne, Institute of Geology and Mineralogy, Zülpicher Straße 49A, 50674 Köln, Germany \\ ${ }^{3}$ Umeå University, Climate Impacts Research Centre (CIRC), 98107 Abisko, Sweden \\ ${ }^{4}$ NEISRI, Russian Academy of Science, Magadan, 685000, Russia \\ *now at: University of Turku, Department of Geography and Geology, Section of Geology, 20014 Turku, Finland \\ ** now at: Helmholtz Centre Potsdam, GFZ German Research Centre for Geosciences, Centre for Geoinformation Technology \\ CeGIT, Telegrafenberg, 14473 Potsdam, Germany \\ *** now at: Institute of Geological Sciences, University of Bern, Baltzerstraße 1+3, Bern, Switzerland \\ ***** now at: Umeå University, Ecology and Environmental Sciences, 98107 Abisko, Sweden
}

Correspondence to: N. R. Nowaczyk (norbert.nowaczyk@gfz-potsdam.de)

Received: 15 May 2013 - Published in Clim. Past Discuss.: 7 June 2013

Revised: 18 September 2013 - Accepted: 26 September 2013 - Published: 1 November 2013

\begin{abstract}
A 318-metre-long sedimentary profile drilled by the International Continental Scientific Drilling Program (ICDP) at Site 5011-1 in Lake El'gygytgyn, Far East Russian Arctic, has been analysed for its sedimentologic response to global climate modes by chronostratigraphic methods. The $12 \mathrm{~km}$ wide lake is sited off-centre in an $18 \mathrm{~km}$ large crater that was created by the impact of a meteorite $3.58 \mathrm{Ma}$ ago. Since then sediments have been continuously deposited. For establishing their chronology, major reversals of the earth's magnetic field provided initial tie points for the age model, confirming that the impact occurred in the earliest geomagnetic Gauss chron. Various stratigraphic parameters, reflecting redox conditions at the lake floor and climatic conditions in the catchment were tuned synchronously to Northern Hemisphere insolation variations and the marine oxygen isotope stack, respectively. Thus, a robust age model comprising more than 600 tie points could be defined. It could be shown that deposition of sediments in Lake El'gygytgyn occurred in concert with global climatic cycles. The upper $\sim 160 \mathrm{~m}$ of sediments represent the past $3.3 \mathrm{Ma}$, equivalent to sedimentation rates of 4 to $5 \mathrm{~cm} \mathrm{ka}^{-1}$, whereas the lower $160 \mathrm{~m}$
\end{abstract}

represent just the first $0.3 \mathrm{Ma}$ after the impact, equivalent to sedimentation rates in the order of $45 \mathrm{~cm} \mathrm{ka}^{-1}$. This study also provides orbitally tuned ages for a total of 8 tephras deposited in Lake El'gygytgyn.

\section{Introduction}

Lake El'gygytgyn in the Far East Russian Arctic $\left(67.5^{\circ} \mathrm{N}\right.$, $172^{\circ} \mathrm{E}$ ) with a diameter of $12 \mathrm{~km}$ is located off-centre in an $18 \mathrm{~km}$ wide impact crater formed 3.58 Ma ago (Layer, 2000). The $170 \mathrm{~m}$ deep lake has a bowl-shaped morphology, a surface area of $110 \mathrm{~km}^{2}$, and a relatively small catchment of $293 \mathrm{~km}^{2}$ (Nolan and Brigham-Grette, 2007). The bedrock in the crater catchment consists mainly of igneous rocks, lavas, tuffs, ignimbrites of rhyolites and dacites, rarely andesites and andesitic tuffs (Gurov and Koeberl, 2004), some of them with ages from 83.2 to $89.3 \mathrm{Ma}$ (Layer, 2000) and $88 \mathrm{Ma}$ (Kelley et al., 1999). Thus, they were emplaced during the Cretaceous normal polarity superchron (Ogg and Smith, 2004). In early 2009, the International Continental 
Scientific Drilling Program (ICDP) drilled through the whole $318 \mathrm{~m}$ thick sedimentary infill and further $199 \mathrm{~m}$ into the impact breccia of the El'gygytgyn crater (Melles et al., 2011). Three parallel sediment cores from ICDP Site 5011-1 (holes 1A, 1B, and 1C) from Lake El'gygytgyn were spliced to make a composite core. For the palaeo-climatic investigation mass movement deposits, like turbidites, and tephra layers were not included, but they are represented by gaps in the respective composite data records. In order to develop a high-resolution age model for the whole sedimentary sequence from Lake El'gygytgyn we used a multi-parameter approach. Major age constraints are provided from a comprehensive magnetostratigraphic investigation of the sediments recovered from holes 5011-1A, 1B, and 1C (Haltia and Nowaczyk, 2013). For refining the initial age model determined by the magnetostratigraphic results, nine additional stratigraphic parameters were synchronously tuned either to the benthic foraminiferal oxygen isotope $\left(\delta^{18} \mathrm{O}\right)$ reference record for the last $5 \mathrm{Ma}$ provided by Lisiecki and Raymo (2005), in general referred to as the LR04 stack, or to the Northern Hemisphere summer insolation according to orbital solutions of Laskar et al. (2004). From the data compilations of Nowaczyk et al. (2002), Nowaczyk et al. (2007), Frank et al. (2013) and the rock magnetic pilot study by Murdock et al. (2013) it became obvious that variations of total organic carbon (TOC) and magnetic susceptibility (MS) mostly reflect the redox conditions at the lake floor, with a predominant stratification (mixing) of the water body and anoxic (oxic) conditions during glacials (interglacials). These redox conditions are obviously controlled by insolation variations, mainly influenced by the 18 and $23 \mathrm{kyr}$ precessional cycles, and, to a lesser extent, the $41 \mathrm{kyr}$ obliquity cycle. Consequently, variations of TOC and MS, together with the intensity of the natural remanent magnetisation (NRM, which in Lake El'gygytgyn sediments, like the MS, mainly reflects the concentration of magnetic particles), were tuned to insolation variations. Since Lake El'gygytgyn is located within the Arctic permafrost region most sedimentary transport and bioproductivity takes place during summer, characterized by superficial thawing of permafrost soils, short vegetation periods in the catchment, and algal growth (mostly diatoms, but also Botriococcus and sometimes snow algae such as Chlamidomonas) in the water body. From midautumn to mid-spring all these processes come to a standstill. Thus, not only the intensity of insolation but also the length of the summer appears to be important for the possibility of sediment transport from the catchment into the lake. Therefore, we used the cumulative summer insolation from May to August for tuning. Variations in tree and shrub pollen percentage and biogenic silica (BSi) represent vegetation conditions in the (wider) area around the lake and bioproductivity within its water body, respectively. Sediment grain size, spectral colour, titanium (Ti) content, and $\mathrm{Si} / \mathrm{Ti}$ ratio, the latter two parameters obtained from X-ray fluorescence (XRF) scanning, reflect mostly weathering and transport processes within and from the catchment, respectively, which in turn depend on climatic conditions. After initial age assignments using magnetic polarity stratigraphy, all these parameters together show striking similarities to global climate variability as expressed by the LR04 stack (Lisiecki and Raymo, 2005), which was therefore used as reference curve. The major environmental implications of the El'gygytgyn palaeoclimate record, occurrence of "super-interglacials" and the stepwise cooling of the Northern Hemisphere are discussed in Melles et al. (2012) and Brigham-Grette et al. (2013), respectively.

In general, age models derived from tuning may include several problems, such as circular reasoning or chronological uncertainties in both the reference record and the record to be tuned, when only restricted sets of data are consulted (Blaauw, 2012). However, wiggle matching can be further validated by using multi-proxy tuning (e.g. Bokhorst and Vandenberg, 2009; Prokopenko et al., 2006), as it was also performed in this study.

\section{Material and methods}

\subsection{Data acquisition}

For magnetostratigraphic investigation the upper $\sim 140 \mathrm{~m}$ of sediments were continuously subsampled with U-channels, whereas the remaining sequences were nearly exclusively analysed by using discrete samples, due to increasing stiffness of the sediments. Determination of the inclination of characteristic remanent magnetization (ChRM), which provides the polarity interpretation, is based on principle component analysis (Kirschvink, 1980) of results from stepwise and complete alternating field demagnetisation of all material. More detailed information on sampling strategy, data acquisition techniques, and methods of processing are given by Haltia and Nowaczyk (2013).

Magnetic (volume) susceptibility from cores PG1351 and Lz1024 were acquired with a Bartington MS2E sensor in combination with a MS2 control unit, integrated into the 1st generation GFZ split-core logger (scl-1.1). Magnetic susceptibility and colour information from sediments from ICDP Site 5011-1 cores were obtained every $1 \mathrm{~mm}$ using a 2nd generation split-core logger (scl-2.3), with its hardware and software designed and built at the Helmholtz Centre Potsdam, GFZ. Magnetic susceptibility was measured with a Bartington MS2E spot-reading sensor first attached to a MS2 control unit, which was later replaced by a technically improved MS3 control unit.

The response function of the MS2E sensor with respect to a thin magnetic layer is equivalent to a Gaussian curve with a half-width of slightly less than $4 \mathrm{~mm}$ (e.g. Fig. 4 in Nowaczyk, 2001). The amplitude resolution of the sensor is $10 \times 10^{-6}$ in combination with the MS2 unit and $2 \times 10^{-6}$ with the improved MS3 unit, both using an integration time of about a second. During data acquisition, after 
every 10 measurements, the sensor is lifted about $4 \mathrm{~cm}$ above the sediment in order to take a blank reading in the air. This is done in order to monitor the shift of the sensor's background due to temperature drift. Subsequently, the air readings were linearly interpolated and subtracted from the readings on sediment.

A spectrophotometer (GretagMacbeth Spectrolino ${ }^{\mathrm{TM}}$ ) was applied with the scl-2.3 logger for acquiring a full colour spectrum from $380 \mathrm{~nm}$ to $720 \mathrm{~nm}$ at a physical resolution of $10 \mathrm{~nm}$ (i.e. providing 36 spectral lines for each measuring spot from ICDP Site 5011-1 cores). For sediments recovered within cores PG1351 and Lz1024 no colour information is available. The spectrophotometer integrates over a circular window of $4 \mathrm{~mm}$ in diameter (centre-weighted). In addition to the visible spectrum further colour information, derived from the spectral data, was transmitted by the instrument: the tristimulus values $(X, Y, Z)$, defined by the International Commission on Illumination (CIE) in 1931, and vectors in the $1976 \mathrm{CIE}\left(L^{*}, a^{*}, b^{*}\right)$ colour space. The tristimulus values of a colour are the amounts of the three colours the human eye can perceive (red, green, blue) in a three-component additive colour model (Fig. 2a). However, in order to reproduce a measured colour represented by $(X, Y, Z)$ (e.g. on a $\mathrm{TV}$ or computer screen) a $3 \times 3$ matrix has to be applied to the $(X, Y, Z)$ vector in order to obtain the required $(R, G, B)$ values for display, as it is implemented in the split-core logger's controlling computer program. The elements of the matrix depend on type of illumination and observing angle, as well as on the $(R, G, B)$ properties of the used hardware and/or computer operating system (or television system).

In the $\left(L^{*}, a^{*}, b^{*}\right)$ colour space (Fig. $\left.2 \mathrm{~b}\right)$, the $a^{*}$ coordinate represents variations in colour between red $\left(a^{*}>0\right)$ and green $\left(a^{*}<0\right)$, whereas the $b^{*}$ coordinate represents variations in colour between yellow $\left(b^{*}>0\right)$ and blue $\left(b^{*}<0\right)$. The $L^{*}$ component represents lightness $(0=$ black, $100=$ white). In order to distinguish major colour changes of the sediments from Lake El'gygytgyn the hue angle $(H)$ was also determined (Fig. $2 \mathrm{~b}$ and c). It is calculated as $H=\operatorname{atan} 2\left(b^{*}, a^{*}\right)$, with $0^{\circ} \leq H \leq 360^{\circ}$. Hue values of major colours are red $=0^{\circ} 360^{\circ}$, yellow $=60^{\circ}$, green $=120^{\circ}$, cyan $=180^{\circ}$, blue $=240^{\circ}$, magenta $=300^{\circ}$. An example of sediment colour, hue angle distribution, and individual colour spectra as obtained with the Spectrolino ${ }^{\mathrm{TM}}$ is shown in Fig. 3.

Since both the susceptibility and colour sensors need to be in full contact to the sediment surface, the scl-2.3 logger is additionally equipped with a third sensor, a high-precision mechanical micro-switch to scan the surface morphology first. This is achieved by moving the switch from a certain reference height downward onto the sediment where the switch triggers the termination of its own movement. Triggering force is in the range of $5 \mathrm{~g}$. The distance moved by the switch is determined by the stepping motor control, thus supplying the information needed for subsequently lowering the susceptibility sensor and the spectrophotometer onto the

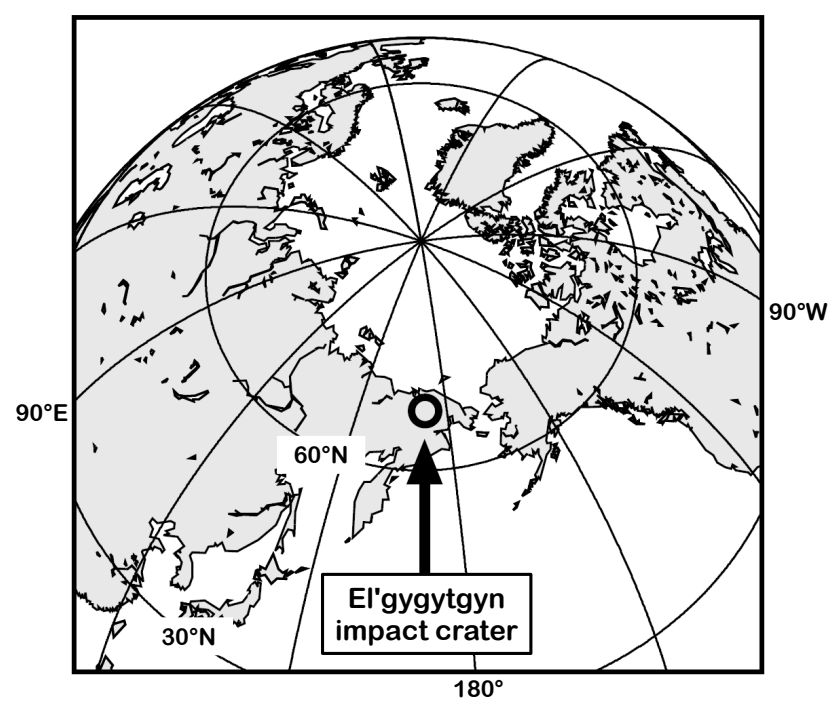

Fig. 1. Location of Lake El'gygytgyn in the Far Eastern Russian Arctic. The circle (not to scale) marks the site of the impact crater.

sediment for data acquisition. During data acquisition core segments were covered by a thin and clear plastic foil in order to prevent all three sensors from being stained by the soft and moist sediments. Ideally, the foil is completely free of air bubbles and clinging to the sediment surface due to sediment moisture. However, the older the sediments are the lower their moisture content is. Thus, downward from about $200 \mathrm{~m}$ on, the foil was not always completely attached to the sediments and colour information got slightly biased with increasing drilling depth due to scattered light.

\subsection{Further data used for tuning}

Biogenic silica (BSi) contents were estimated at a sampling interval of $20 \mathrm{~mm}$ by using Fourier transform infrared spectroscopy (FTIRS). The method is described in detail by Vogel et al. (2008) and Rosén et al. (2010, 2011). Biogenic silica is mostly derived from diatoms, which are the major contributors to the intra-lake bioproduction (e.g. Cherapanova et al., 2007). Post-sedimentary dissolution of diatom frustules is negligible in sediments of Lake El'gygytgyn. Thus, the percentage of biogenic silica is taken as a proxy for bioproductivity in Lake El'gygytgyn. A detailed discussion on FTIRS results from ICDP Site 5011-1 is provided by Meyer-Jacob et al. (2013) and Vogel et al. (2013).

The content of total organic carbon (TOC) was determined every $20 \mathrm{~mm}$ using a Vario microCube elemental analyzer (Elementar, Germany). Elemental scans of major elements were performed with an ITRAX XRF (X-ray fluorescence) core scanner (Cox Analytical, Sweden), equipped with $\mathrm{Cr}$ - and Mo-tubes, respectively, which were set to $30 \mathrm{kV}$ and $30 \mathrm{~mA}$. The abundance of elements was determined at $2 \mathrm{~mm}$ resolution with an integration time of $10 \mathrm{~s}$ per measurement. The relative abundance of titanium (Ti) is taken as 


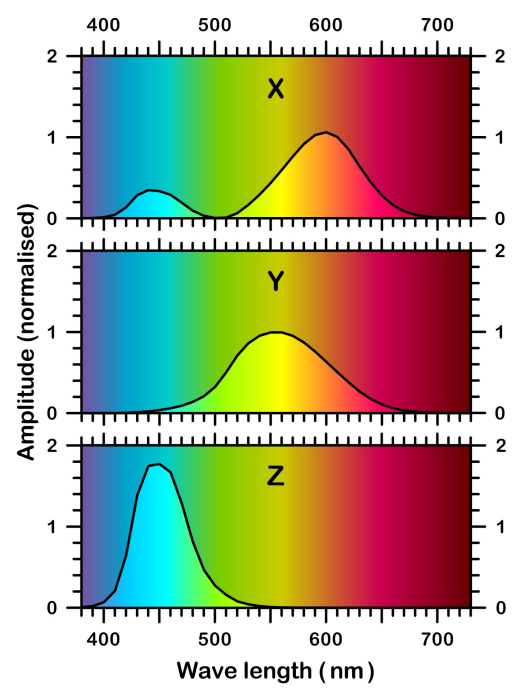

a)

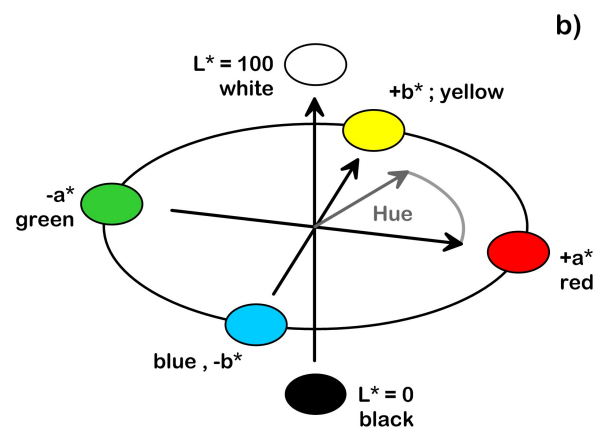

c)

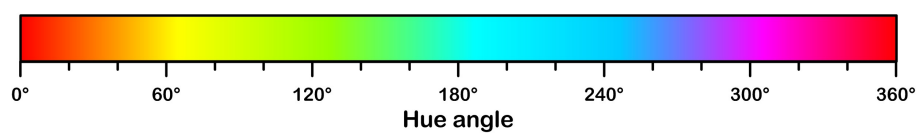

Fig. 2. Some basics in colour processing: (a) $2^{\circ}$-observer weighting functions for spectrum integration in order to obtain the tristimulus values $(X, Y, Z),(\mathbf{b}) L^{*} a^{*} b^{*}$ colour space and definition of the hue angle as also shown in (c), together with corresponding colours. Note that colours are more schematic rather than realistic.

a proxy of clastic lithogenic input, whereas silica $(\mathrm{Si})$ represents the sum of both lithogenic and biogenic Si. Thus, the $\mathrm{Si} / \mathrm{Ti}$ ratio reflects the variable contribution of biogenic silica against the clastic lithogenic background. For further details see Wennrich et al. (2013). Grain-size variability was estimated by principle component analysis (PCA) of granulometric analyses using a laser particle analyzer (Francke et al., 2013). For tuning of the ICDP-5011-1 composite record PC 1 (principle component 1) was used, with negative (positive) values representing coarse (fine) grained sediments. Pollen data is available every $8 \mathrm{~cm}$, with lower resolution in the Pliocene section (see also Andreev et al., 2013 and Lozhkin and Andersen, 2013). Where available, the percentage of tree and shrub pollen was used as an additional environmental indicator with high (low) percentages representing warm (cold) conditions. Data from PG1351 are from Nowaczyk et al. (2002), data from Lz1024 are from Lozhkin et al. (2007).

\subsection{Creation of a composite}

For analysis of the Lake El'gygytgyn sedimentary succession a composite was created using data from core Lz1024, recovered in 2003, and from ICDP Site 5011-1, comprising only partly overlapping holes $1 \mathrm{~A}, 1 \mathrm{~B}$, and $1 \mathrm{C}$, recovered in 2009 . From the 16.64-metre-long core Lz1024 data records of the upper $5.67 \mathrm{~m}$ were used to supplement the uppermost section of the composite that was not recovered with ICDP Site 5011-1 cores. According to initial data analyses, this depth interval is equivalent to marine oxygen isotope stages (MIS) 1 to 4 and most of MIS 5 (back to about $125 \mathrm{ka}$ ). Below $5.67 \mathrm{~m}$, and until about $104.8 \mathrm{~m}$ composite depth, alternating sediment intervals from parallel holes 5011-1A and 1B were spliced together. Between $104.8 \mathrm{~m}$ and $113.4 \mathrm{~m}$ composite depth additional information from core 5011-1C could be used. Between $113.4 \mathrm{~m}$ and $145.7 \mathrm{~m}$ composite depth, cores $1 \mathrm{~A}$ and $1 \mathrm{C}$ contributed to the composite. Below $145.7 \mathrm{~m}$ composite depth down to the sediment impact breccia interface at $318 \mathrm{~m}$, only core $5011-1 \mathrm{C}$, which has a mean recovery rate of only $50 \%$ (Melles et al., 2011), could be used. However, at least the lowermost $38 \mathrm{~m}$ of the composite (280 to $318 \mathrm{~m}$ ) is available with 90 to $99 \%$ recovery.

Core intervals for the composite were selected mainly by visual inspection, using the better preserved/least disturbed sections from one of the records in cases of overlapping recovery. In general, tephra layers, turbidites, and mass movements were omitted leaving gaps within the composite data sets. Further details are described by Wennrich et al. (2013).

\subsection{Tuning}

Fixed age tie points for the ICDP Site 5011-1 composite record are provided by magnetostratigraphic investigation of sediments from this site by Haltia and Nowaczyk (2013). Ages for the documented major reversals were mainly assigned according to Lisiecki and Raymo (2005) as listed in Table 1. Between the tie points provided by 


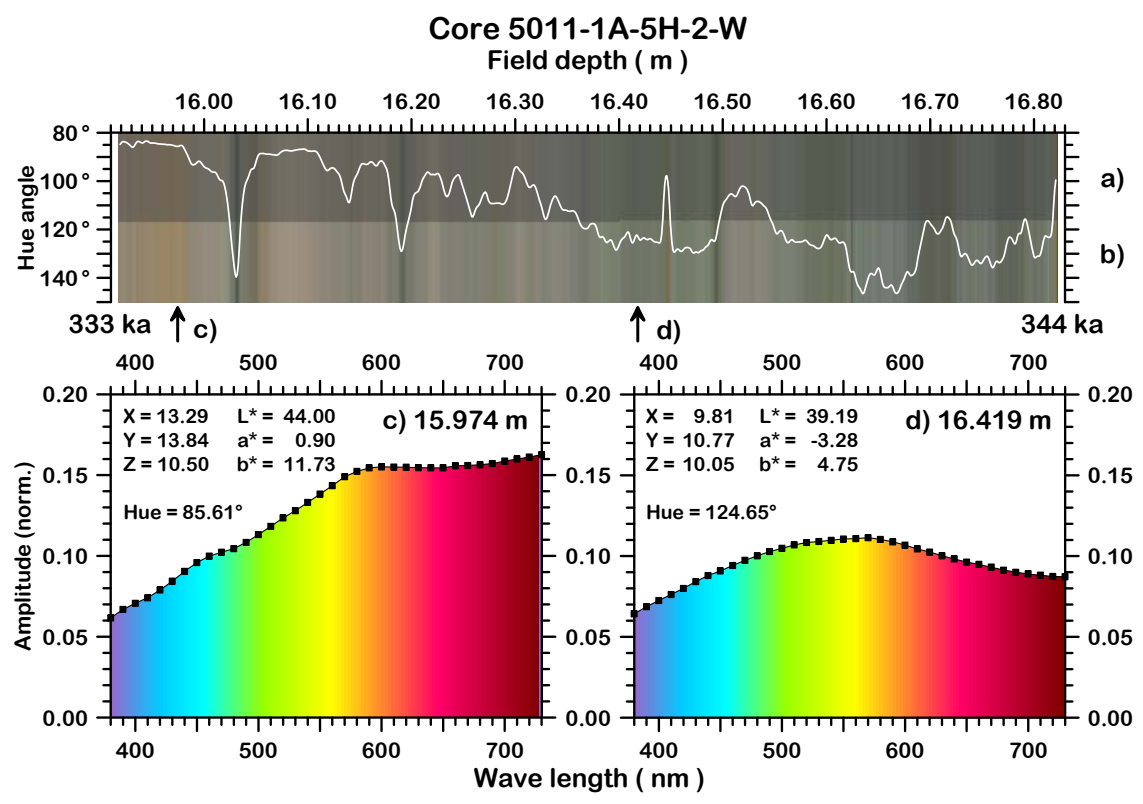

Fig. 3. Example for quantitative colour data acquisition from core 5011-1A-5H-W in field depth across Termination IV (time interval from 344 to $333 \mathrm{ka}$ ): (a) original and (b) contrast-enhanced down-core variation of colours measured with a GretagMacbeth Spectrolino ${ }^{\text {TM }}$ spectrophotometer, together with hue angle (white curve), (c) and (d) two individual spectra including tristimulus values $(X, Y, Z),\left(L^{*}, a^{*}, b^{*}\right)$ values, hue angle (see Fig. 2), and logging depth. The positions of the two measuring points are marked by arrows below (b).

magnetostratigraphy, a synchronous tuning of nine additional data sets was performed using an interactive wiggle matching software. The extended tool for correlation (xtc, Linux-based) is capable of loading all necessary data sets together into the memory of the computer (down-core data sets, reference data sets, age models, positions of tephras, scaling of axes). The (partly huge) sizes of the data sets used for tuning are listed in Table 2. In all, $1 \mathrm{~mm}$ spot-readings of magnetic susceptibility and TOC data, determined every 10 to $20 \mathrm{~mm}$, were tuned to the Northern Hemisphere $\left(67.5^{\circ} \mathrm{N}\right.$, El'gygytgyn latitude) cumulative spring-summer insolation (May to August) according to Laskar et al. (2004). Parallel to this, $\mathrm{Ti}$ as well as $\mathrm{Si} / \mathrm{Ti}$ ratios based on $2 \mathrm{~mm}$ readings of $\mathrm{X}$ ray fluorescence (XRF) counts, percentages of biogenic silica (BSi, opal) derived from Fourier transform infrared spectroscopy (FTIRS), determined every $20 \mathrm{~mm}$, the hue angle determined every $1 \mathrm{~mm}$, grain size PCA data, and tree pollen percentages (where available) were tuned to the LR04 marine oxygen isotope stack of Lisiecki and Raymo (2005). Jointly to the tuning of the ICDP Site 5011-1 data sets, age models for the Lake El'gygytgyn pilot cores were also developed (Lz1024) and refined (PG1351).

\section{Results}

The intention was to provide a sedimentary palaeoclimatic proxy-record that is cleaned of tephra layers, turbidites, slumps, and other disturbances, such as folded sediments. Therefore, these intervals were discarded for the creation of the ICDP Site 5011-1 composite. However, these sediment intervals can still provide useful information at least about the polarity of the geomagnetic field during their deposition. The expected dipole inclination for the site of Lake El'gygytgyn is $78.3^{\circ}$. Thus, folded layers with a tilt of, for example, $45^{\circ}$ will still yield positive (negative) inclination during normal (reversed) polarity. It then depends on the angle between magnetization direction and tilting direction whether the disturbed direction is shallower or steeper than the undisturbed one. Also turbidites, although representing short depositional events on a geological timescale, should record a polarity if not an accurate palaeomagnetic direction at least in their upper fine-grained section. Therefore, in intervals close to reversals, the directional data of rejected intervals, such as the onset of the Olduvai subchron and reversals within the Gauss chron (see Haltia and Nowaczyk, 2013), were also taken into consideration when determining the polarity and localization of the major reversals.

\subsection{Iterative tuning}

The general strategy of tuning is demonstrated by data covering the time window from $740 \mathrm{ka}$ to $1000 \mathrm{ka}$, comprising the Brunhes Matuyama reversal as well as the termination of the Jaramillo subchron (Fig. 4). Note that for reasons of clarity not all resulting correlation tie points within this interval are displayed. The major reversals of the earth's magnetic field, as incorporated in the official geomagnetic polarity timescale (GPTS, Ogg and Smith, 2004; Table 1), provide twelve 1st 
Table 1. Ages of geomagnetic reversals from various authors, listed in the first row, and as inferred from multi-proxy tuning of ICDP Site 5011-1 sediments from Lake El'gygytgyn in this study, listed in the right column. Here, bold numbers indicate new/alternative ages, otherwise ages were adopted from Lisiecki and Raymo (2005).

\begin{tabular}{|c|c|c|c|c|c|}
\hline Authors & $\begin{array}{r}\text { Cande and Kent } \\
\text { (1995) }\end{array}$ & $\begin{array}{r}\text { Lourens et al. } \\
\text { (1996) }\end{array}$ & $\begin{array}{r}\text { Ogg and Smith } \\
(2004)\end{array}$ & $\begin{array}{r}\text { Lisiecki and } \\
\text { Raymo (2005) }\end{array}$ & This study \\
\hline \multirow{2}{*}{$\begin{array}{l}\text { Reversal } \\
\text { subchron } \\
\text { cryptochron/excursion }\end{array}$} & \multicolumn{5}{|c|}{ Age } \\
\hline & $\mathrm{Ma}$ & Ma & Ma & Ma & $\mathrm{Ma}$ \\
\hline Brunhes/Matuyama & 0.780 & & 0.781 & 0.780 & 0.780 \\
\hline Jaramillo (t) & 0.990 & & 0.988 & 0.991 & 0.991 \\
\hline intra-Jaramillo excursion $(t)$ & & & & & 1.0142 \\
\hline intra-Jaramillo excursion (o) & & & & & 1.0192 \\
\hline Jaramillo (o) & 1.070 & & 1.072 & 1.075 & 1.075 \\
\hline Cobb-Mountain $(t)$ & 1.201 & & 1.173 & & 1.1858 \\
\hline Cobb-Mountain (o) & 1.211 & & 1.185 & & 1.1938 \\
\hline Olduvai (t) & 1.770 & 1.785 & 1.778 & 1.781 & 1.781 \\
\hline Olduvai (o) & 1.950 & 1.942 & 1.945 & 1.968 & 1.968 \\
\hline Olduvai precursor $(t)$ & & & & & 1.9782 \\
\hline Olduvai precursor (o) & & & & & 1.9815 \\
\hline La Réunion $(t)$ & 2.140 & 2.129 & 2.128 & & 2.1216 \\
\hline La Réunion (o) & 2.150 & 2.149 & 2.148 & & 2.1384 \\
\hline Matuyama/Gauss & 2.581 & 2.582 & 2.581 & 2.608 & 2.588 \\
\hline Kaena $(t)$ & 3.040 & 3.032 & 3.032 & 3.045 & 3.045 \\
\hline Kaena (o) & 3.110 & 3.116 & 3.116 & 3.127 & 3.127 \\
\hline Mammoth (t) & 3.220 & 3.207 & 3.207 & 3.210 & 3.210 \\
\hline Mammoth (o) & 3.330 & 3.330 & 3.330 & 3.319 & 3.319 \\
\hline Gauss/Gilbert & 3.580 & 3.596 & 3.596 & 3.588 & 3.588 \\
\hline
\end{tabular}

Here: $\mathrm{o}$ - onset, $\mathrm{t}$ - termination.

order tie points (red dotted lines in Fig. 4) during the last 3.6 Ma for the age model, from which ten are very well defined in the El'gygytgyn sedimentary sequence. Only the top of the Kaena and the base of the Mammoth subchrons, both within the Gauss chron, are somewhat ambiguous, when only (cleaned) palaeomagnetic information are considered. Additional two 1st order tie points could be derived from the short Cobb Mountain event (Mankinen et al., 1978) within the Matuyama Chron, clearly linked to MIS 35 (Channell et al., 2008). Figure 4 comprises the Brunhes Matuyama reversal and the termination of the Jaramillo subchron as 1st order tie points. For the base of the lacustrine sediment section from Lake El'gygytgyn the age of the impact of $3.58 \pm 0.04 \mathrm{Ma}$ was adopted from Layer (2000) as another 1st order tie point.

After adopting this approach to convert depths into ages it became obvious that the morphology of the $\log (\mathrm{Si} / \mathrm{Ti}$ ratio) curve obtained from XRF scanning resembles the LR04 oxygen isotope reference curve from Lisiecki and Raymo (2005) quite well (Fig. 4b, d). The same is valid for the Ti content and the hue angle, when both plotted on an inverse axis (not shown in Fig. 4), and partly the record of biogenic silica obtained from Fourier transform infrared spectroscopy (FTIRS-BSi), which mainly resembles the so-called super-interglacials (Melles et al., 2012) from above a certain threshold level (Fig. 4a). This set of proxy records therefore was used to define 2 nd order tie points (dark green shortdashed lines in Fig. 4) by interactive wiggle matching to the LR04 curve.

Compared to the LR04 stack, the Northern Hemisphere summer insolation shows a much stronger variability. Note that already the onsets of interglacials, MIS 19, 21, and 25, are linked to pronounced insolation maxima. In the further course of these interglacials one (MIS 19 and 25) or even two insolation minima occur (MIS 21). These minima and most of all other minima in insolation are obviously linked to lows in magnetic susceptibility and highs in TOC when applying 1st and 2nd order tie points for correlation. Figure 5 shows a simplified sketch of interdependencies of sedimentary properties versus insolation variations. Minima in insolation trigger anoxic conditions at the lake floor associated with severe dissolution of magnetic minerals (low magnetic susceptibility) but best preservation of organic matter (high TOC values). The termination of such phases coincide fairly well with the steepest gradient of increasing insolation after the preceding insolation minimum, and the beginning of intervals characterized by high susceptibility. Insolation maxima mark the beginning of periods with high bioproductivity. Nevertheless, due to dominating oxic bottom water 
Table 2. Overview of stratigraphic data used for multi-proxy tuning of Lake El'gygytgyn sediments: number of obtained logger readings or individual determinations, with numbers in italics indicating raw data that was acquired on the full stratigraphic lengths of the respective cores. Scanning/sampling intervals are given below the parameter notation.

\begin{tabular}{|c|c|c|c|c|c|c|c|}
\hline Data set & $5011-1 A$ & $5011-1 B$ & $5011-1 C$ & 5011 comp. & Lz1024 & PG1351 & total \\
\hline $\operatorname{MS} 2 E^{a}$ & 122939 & 100606 & 95264 & 143752 & 16026 & 11050 & 489637 \\
\hline $1 \mathrm{~mm}$ & & & & & & & \\
\hline $\begin{array}{l}\text { colour }{ }^{\mathrm{b}} \\
1 \mathrm{~mm}\end{array}$ & 122988 & 101074 & 99060 & 138623 & no & no & 461745 \\
\hline $\begin{array}{l}\mathrm{XRF}^{\mathrm{c}} \\
2 \mathrm{~mm}\end{array}$ & 61357 & 50132 & 46464 & 71263 & 8273 & 186 & 237675 \\
\hline $\begin{array}{l}\text { NRM, ChRM } \\
2(10-15) \mathrm{cm}^{\mathrm{d}}\end{array}$ & 5806 & 4848 & 2113 & 5883 & 607 & 476 & 19733 \\
\hline $\begin{array}{l}\text { biog. Silica } \\
\text { (1) } 2 \mathrm{~cm}\end{array}$ & no & no & no & 5856 & 1657 & 229 & 7742 \\
\hline $\begin{array}{l}\text { TOC } \\
\text { (1) } 2 \mathrm{~cm}\end{array}$ & no & no & no & 6136 & 1658 & 334 & 7847 \\
\hline $\begin{array}{l}\text { grain size } \\
8 \mathrm{~cm}\end{array}$ & no & no & no & 1125 & no & no & 1125 \\
\hline $\begin{array}{l}\text { Tree polleng } \\
5-6(30-300) \mathrm{cm}\end{array}$ & & & & 392 & 184 & 124 & 556 \\
\hline
\end{tabular}

\footnotetext{
a magnetic susceptibility, ${ }^{\mathrm{b}}$ full visible colour spectrum (36 lines), $(X, Y, Z)$ tristimulus values, $\left(L^{*}, a^{*}, b^{*}\right)$, hue angle, ${ }^{\mathrm{c}} \mathrm{X}$-ray fluorescence spectra, abundance of major elements ${ }^{d}$ natural remenent magnetisation (NRM) and characteristic remanent magnetisation (ChRM) from U-channels, sampling interval for discrete samples in brackets, ${ }^{\mathrm{e}}$ from Fourier Transform Infrared Spectrocopy (FTIRS-BSi), sampling interval for Lz1024 in brackets, ${ }^{\mathrm{f}}$ total organic carbon, sampling interval for Lz1024 in brackets, ${ }^{\mathrm{g}}$ sampling interval for Pliocene interval in ICDP Site 5011-1 cores in brackets.
}

conditions, organic matter gets degraded (low TOC values), whereas magnetic minerals are being widely preserved, leading to high values in magnetic susceptibility, although the lithogenic contribution is lower than during glacials. During the super-interglacials (Melles et al., 2012), characterized by exceptional high biogenic silica values and high $\mathrm{Si} / \mathrm{Ti}$ ratios - such as MIS 5, 9, 11, 17, 25 (see Fig. 4), 31, 47, and 49 (see also Supplement) - the high deposition rate of biogenic matter is the major controlling factor for modulating values of both magnetic susceptibility and TOC. The increased flux of organic matter into the sediment partly overwhelms degradation processes in oxic bottom waters, leading to intermediate values in both TOC and magnetic susceptibility. A fast oxygen consumption in the sub-bottom pore water has to be assumed which hampered a further sub-surface degradation of organic matter. Thus in total, a partial degradation of organic matter should have occurred so that the associated TOC peaks very likely give an underestimation of the primary bioproductivity (Nowaczyk et al., 2002, 2007). Magnetic susceptibility values are mostly controlled by the high primary bio-production and thus a by dilution of lithogenic compounds. Further on due to oxygen depletion in the pore waters, a partial dissolution of magnetic minerals has to be taken into account, since susceptibility values cannot be explained by dilution by biogenic compounds alone. Another special case is that of a glacial supposedly much moister than others (Melles et al., 2007). Due to increased snowfall and thus reduced light transmission, bioproductivity below the ice cover is significantly lower than during dry glacials. During dry glacials, Lake El'gygytgyn was supposed to be covered by clear ice, that is, with little to no snow on it, associated with a high light transmission, and thus better growing conditions for algae. Considering all these interdependencies, 3rd order tie points could be defined for fine-tuning (blue long-dashed lines in Fig. 4).

\subsection{Chronostratigraphy and precision of age model}

Figure 6 shows the most important parameters from ICDP Site 5011-1 composite record after synchronous tuning to the GPTS, the LR04 stack, and the Northern Hemisphere summer insolation. The parameters that were mainly tuned to the LR04 marine oxygen isotope stack (Fig. 6f) are plotted in the left section (Fig. 6a to e): grain size variations, hue angle (sediment colour), biogenic silica (FTIRS-BSi), $\mathrm{Si} / \mathrm{Ti}$ ratio from XRF-scanning, and tree and shrub pollen percentages where available, including results from pilot cores PG1351 and Lz1024. The ChRM inclinations of the ICDP Site 5011-1 composite record (Fig. 6g) is plotted to the right of the LR04 stack. Geomagnetic field reversals can be recognized from flips between steep positive inclinations (normal polarity, grey background) and steep negative inclinations (reversed polarity, white background). Thus, the ICDP Site 5011-1 sedimentary record comprises the three geomagnetic chrons including Brunhes, Matuyama, and (most of the) Gauss (i.e. the last about 3.6 Ma). The right section of Fig. 6 relates variations of total organic carbon (TOC, 


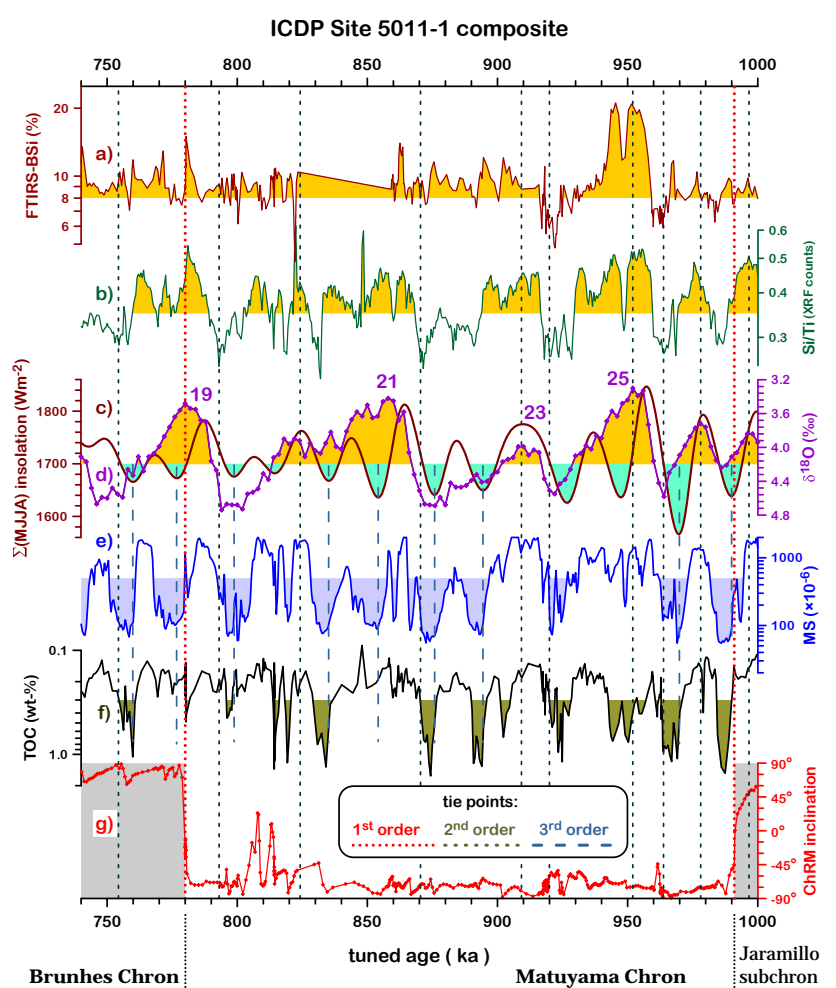

Fig. 4. Definition of 1 st, 2 nd, and 3rd order tie points of the age model: Chronostratigraphic plot for the time window $740 \mathrm{ka}$ to $1000 \mathrm{ka}$ of (a) biogenic silica (FTIRS-BSi), (b) Si / Ti ratio, with high (low) ratios indicating higher (lower) biogenic input with respect to lithogenic input, (c) cumulative summer (May to August) insolation for $67.5^{\circ} \mathrm{N}$ (according to Laskar et al., 2004), (d) LR04 oxygen isotope stack $\left(\delta^{18} \mathrm{O}\right)$ from Lisiecki and Raymo (2005), (e) magnetic susceptibility (MS), (f) total organic carbon (TOC), and (g) ChRM inclination, with grey (white) indicating normal (reversed) polarity. Geomagnetic field reversals are defined as 1st order tie points of the age model. Correlation of $\mathrm{Si} / \mathrm{Ti}$ ratio and biogenic silica to the LR04 stack define 2nd order tie points, and correlation of magnetic susceptibility and TOC to insolation patterns define 3rd order tie points. For further details, see text. FTIRS - Fourier transform infrared spectroscopy, XRF - X-ray fluorescence, ChRM characteristic remanent magnetization.

Fig. 6h) and magnetic susceptibility (Fig. 6i) to the Northern Hemisphere insolation (cumulative, May to August, $67.5^{\circ} \mathrm{N}$, Fig. 6j). The obtained age model of the ICDP 5011 composite is shown in Fig. 7 and age models for the pilot cores, PG1351 and Lz1024, are shown in Fig. 8. Mean sedimentation rates in Lake El'gygytgyn are in the range of $4 \mathrm{~cm} \mathrm{ka}^{-1}$ for the last about 1.0 Ma. Going further back in time, sedimentation rates slightly increase to about $5 \mathrm{~cm} \mathrm{ka}^{-1}$ roughly between 2.5 and 3.0 Ma, whereas the interval between 3.3 and 3.6 Ma is characterized by ten-fold higher sedimentation rates of about $45 \mathrm{~cm} \mathrm{ka}^{-1}$. This must be due to major environmental changes. In the marine LR04 oxygen isotope stack the oldest shift towards heavier values during the past $3.6 \mathrm{Ma}$,

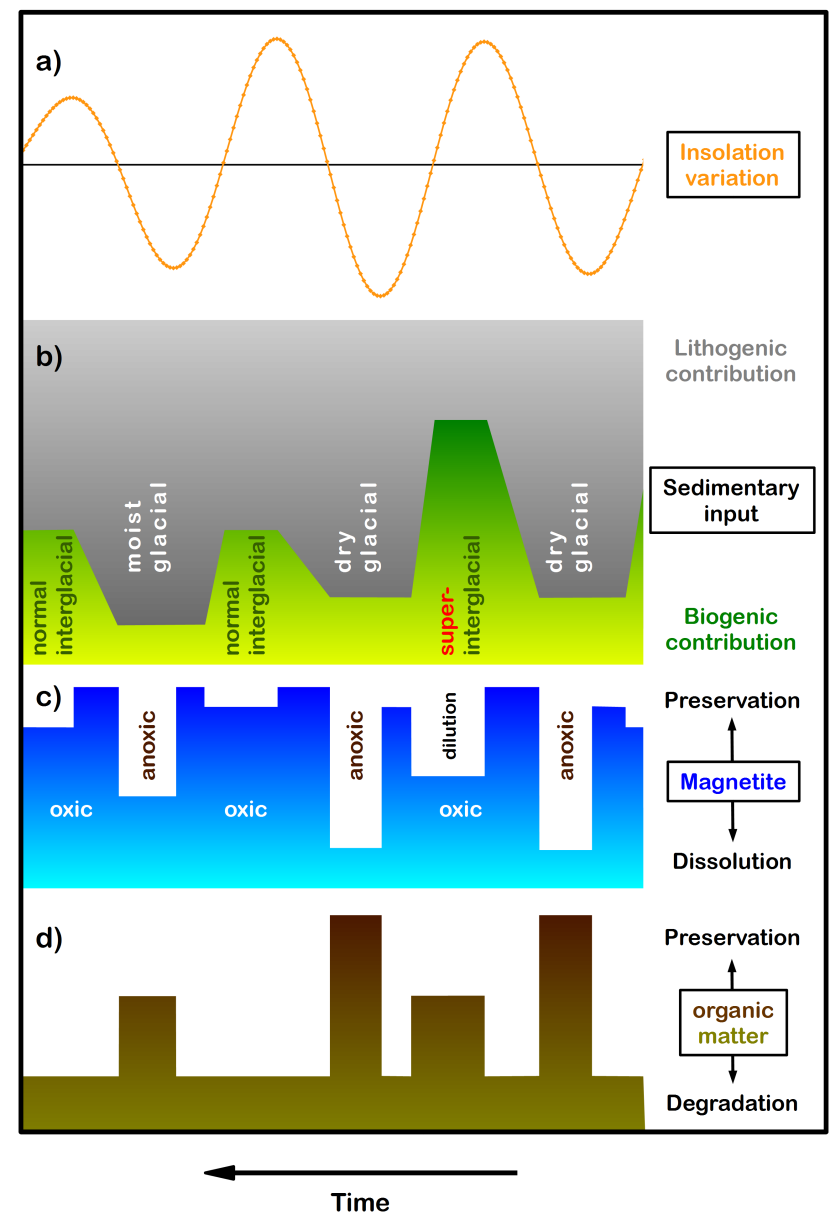

Fig. 5. Simplified sketch of interdependencies of Lake El'gygytgyn sedimentary properties with orbital forcing throughout the Pleistocene: (a) variation of summer insolation, (b) lithogenic versus biogenic sedimentary input, (c) magnetic susceptibility, and (d) concentration of organic matter. For detailed explanation see text.

MIS M2 within the early Mammoth subchron, occurs around 3.3 Ma (see supporting online material for a more detailed display and labelling of data). This is parallelled by a drastic drop in tree and shrub pollen percentage down to $20 \%$ in the sedimentary record of Lake El'gygytgyn. Furthermore, this actually substantiated the position of the onset of the Mammoth subchron in the ICDP Site 5011-1 record, since here the interpretation of palaeomagnetic data is hampered by numerous recovery gaps and low core quality.

In the first place, the precision of the age model(s) of Lake El'gygytgyn sediments is limited by the accuracy, precision and temporal resolution of the reference curves. The LR04 oxygen isotope stack for the last $5 \mathrm{Ma}$ is provided in $1 \mathrm{kyr}$ increments. Lisiecki and Raymo (2009) point out that especially the timing of glacial terminations documented in benthic oxygen isotope records from the Atlantic and the Pacific can already differ by up to $4 \mathrm{kyr}$. This problem accounts mainly for new marine benthic oxygen isotope records to be 


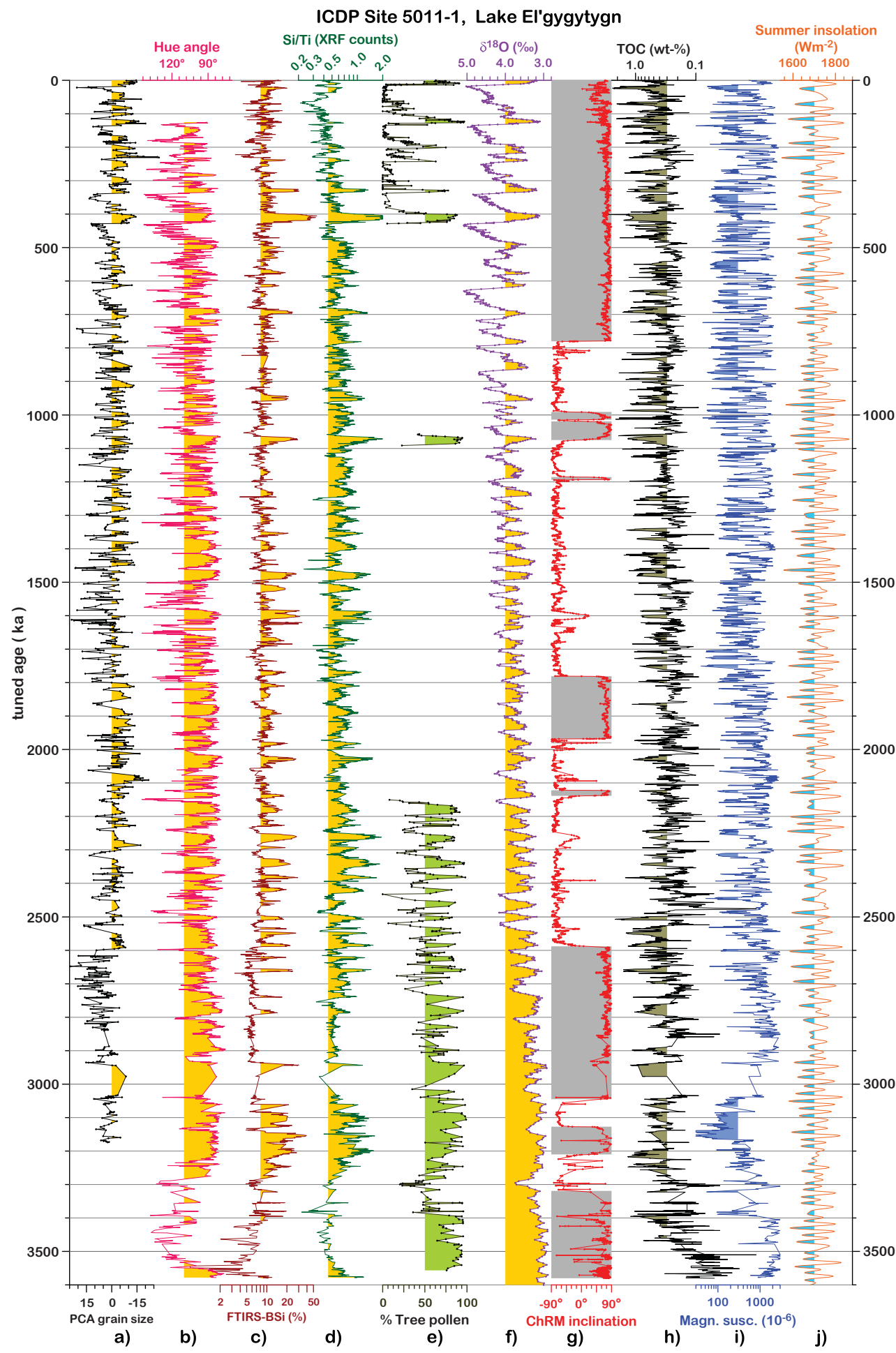

Fig. 6. Chrono-stratigraphic plot of main parameters used for developing the age model of the ICDP Site 5011-1 composite record from Lake El'gygytgyn: (a) grain size data from principle component analysis (PCA), with negative (positive) values representing coarse (fine) grained sediments, (b), hue angle from photospectrometry (see Fig. 2), (c) biogenic silica from Fourier transform infrared spectroscopy (FTIRS-BSi), (d) $\mathrm{Si}$ / Ti ratio from X-ray fluorescence (XRF) scanning, (e) tree and shrub pollen percentages, (f) marine oxygen isotope stack (Lisiecki and Raymo, 2005), (g) inclination of the characteristic remanent magnetisation (ChRM), with grey (white) indication normal (reversed) polarity, (h) total organic carbon (TOC), (i) magnetic susceptibility, and (j) the cumulative Northern Hemisphere summer insolation (May to August), according to orbital solutions provided by (Laskar et al., 2004). 


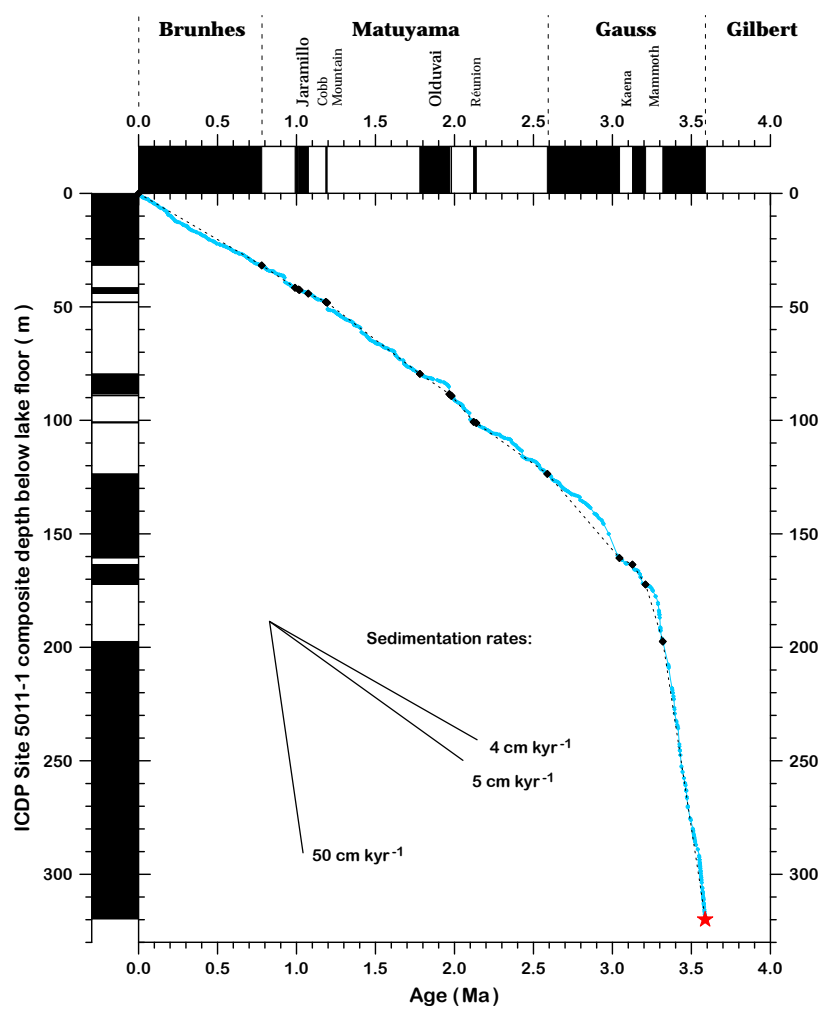

Fig. 7. Age depth model for the ICDP Site 5011-1 sedimentary composite record derived from tuning of physical, sedimentological, geochemical, and pollen records to the benthic oxygen isotope stack from Lisiecki and Raymo (2005) and the Northern summer insolation according to orbital solutions provided by (Laskar et al., 2004), respectively. Initial 1st order tie points (black diamonds) were provided by a comprehensive magnetostratigraphic investigation of ICDP Site 5011-1 cores (Haltia and Nowaczyk, 2013; see also Fig. 2). The red star marks the time of the impact inferred from ${ }^{40} \mathrm{Ar} /{ }^{39} \mathrm{Ar}$ dating (Layer, 2000) at $3.58( \pm 0.04) \mathrm{ka}$. Black (white) denote normal (reversed) polarity.

dated by correlation to a master record. However, the LR04 stack/master record is based on records with a global distribution, including the Atlantic and Pacific Oceans, so that stratigraphic correlation to it might introduce inaccuracies in dating in the range of several kyrs. The LR04 stack has been tuned to the 21 June insolation at $65^{\circ} \mathrm{N}$ according to orbital solutions of Laskar et al. (1993). Because of uncertainties in these solutions, Lisiecki and Raymo (2005) conclude that absolute ages in their LR04 stack might be offset by several kyrs, depending on time interval: up to $4 \mathrm{kyr}$ from 0 to $1 \mathrm{Ma}$, up to $6 \mathrm{kyr}$ from 1 to $3 \mathrm{Ma}$, up to $15 \mathrm{kyr}$ from 3 to $4 \mathrm{Ma}$. In addition to usage of the LR04 stack as stratigraphic reference, we tuned magnetic susceptibility and TOC variations from Lake El'gygytgyn sediments to updated orbital solutions given in increments of $0.25 \mathrm{kyr}$ and with an uncertainty of $0.1 \%$ according to Laskar et al. (2004). Thus, tuning data with ages around 3 Ma might be offset by only

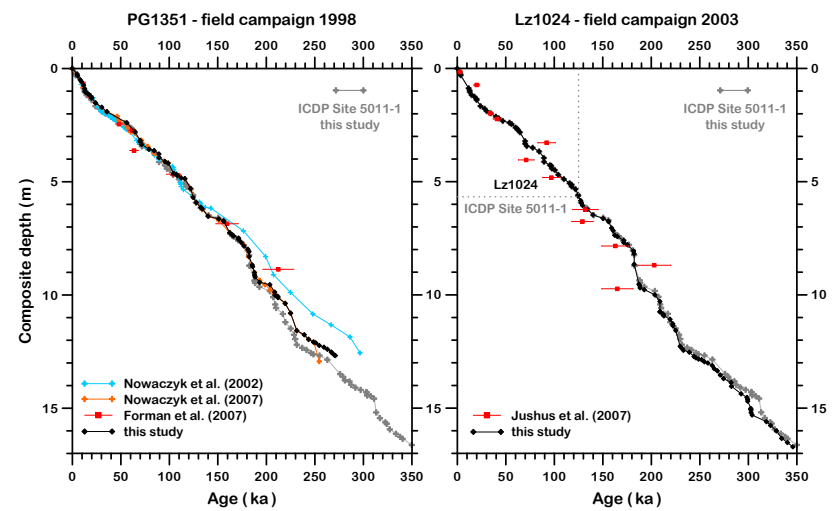

Fig. 8. Age depth models for pilot cores PG1351 (1998) and Lz1024 (2003) after synchronizing with ICDP Site 5011-1 age model (Fig. 7). Red squares with error bars mark results from infrared stimulated luminescence (IRSL) dating. The dotted line in the right graph mark the junction between Lz1024 and the ICDP Site 5011-1 composite record, assembled from cores 5011-1A, -1B, and $-1 \mathrm{C}$.

3 kyr. Therefore, absolute ages of El'gygytgyn sediments are possibly offset by up to about $3 \mathrm{kyr}$ (considering Laskar et al., 2004) to $15 \mathrm{kyr}$ (considering Lisiecky and Raymo, 2005) in the Pliocene, but relative age assignments to the reference records should have a precision of some $500 \mathrm{yr}$ since many (3rd order) tie points were derived from the insolation reference record, which has a higher temporal resolution.

\section{Discussion}

\subsection{Age of meteorite impact}

The lowermost distinctly stratified sediments recovered from Lake El'gygytgyn clearly show normal polarity. Some intercalations of suevitic material in this section imply that these sediments must have been deposited shortly after the impact. The suevites are supposed to have been episodically washed in from the intra-crater catchment. Palaeomagnetic data from the underlying suevites show predominantly a normal polarity, too (Maharaj et al., 2013). Thus, it can be concluded, that the impact that created the El'gygytgyn Crater occurred definitely after the Gauss-Gilbert reversal (Table 1). However, it is not clear how long it took to form a permanent lake within the impact crater and when it came to a persistent deposition of sediments into it. Figure 9 shows the dating of the impact by Layer (2000) within the context of the geomagnetic polarity timescale(s). The $1 \sigma$ error range of the dating $(3.58 \pm 0.04 \mathrm{Ma})$ crosses the Gauss-Gilbert reversal. Thus, the only conclusion that can be drawn is that the older (upper) limit for the age of the impact can be set to $3.588 \mathrm{Ma}$, when adopting the LR04 timescale, or to $3.596 \mathrm{Ma}$ when using the Ogg and Smith (2004) GPTS. Unfortunately, no biogenic remnants (neither diatoms, nor pollen) that would 


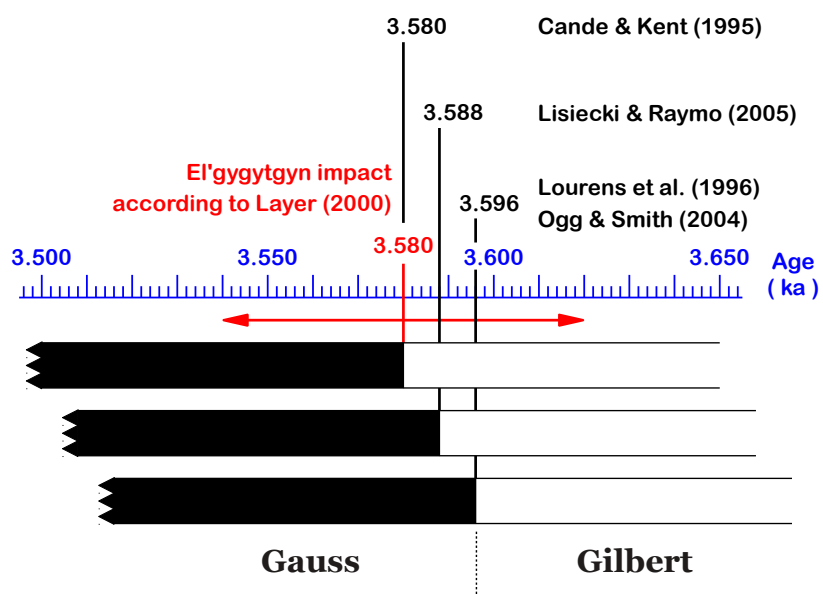

Fig. 9. Radiometric dating of the El'gygytgyn impact (Layer, 2000) in the context of currently used geomagnetic polarity timescales. Since the lowermost ICDP Site 5011-1 sediments show clear normal polarity directions, the impact must have occurred after the Gilbert Gauss reversal.

allow assignments to climate cycles are preserved within the lowermost about $25 \mathrm{~m}$ of sediments. Therefore, the younger (lower) limit of the impact age of 3.540 Ma is still defined by the $1 \sigma$ error range of Layer (2000).

\subsection{Polarity stratigraphy}

In general, as listed in Table 1, our multi-proxy study of the Lake El'gygytgyn ICDP Site 5011-1 sedimentary record confirms ages of geomagnetic reversals within the past 3.6 Ma as given by Lisiecki and Raymo (2005). Table 1 lists also ages of known reversals provided in the geomagnetic polarity times scales (GPTS) of Cande and Kent (1995), Lourens et al. (1996), and Ogg and Smith (2004), since Lisiecki and Raymo (2005) do not provide ages for all of them. In addition to this, reversal ages listed in the various GPTSs slightly deviate from each other.

Palaeomagnetic data quality of the Gauss chron at ICDP Site 5011-1 is very heterogeneous since it is based mainly on a single core, ICDP 5011-1C (Haltia and Nowaczyk, 2013). Normal polarity in its earliest part is very well established. But between $\sim 3.55$ and $\sim 2.95 \mathrm{Ma}$ (290 and $145 \mathrm{~m}$ composite depth) directions are fairly scattered due to numerous recovery gaps and bad core quality, with at least some increase of data coverage around the middle Gauss normal polarity phase. Thus, the onset of the Mammoth and the termination of the Kaena reversed polarity subchrons are not clearly expressed. However, using the available data set of climate-proxy parameters a fairly robust age model could be achieved even for this interval. From $\sim 2.95 \mathrm{Ma}$ on $(290 \mathrm{~m}$ composite depth) the ICDP 5011-1 composite is based on at least two cores and normal polarity within the upper Gauss chron is well expressed.
According to our study, the Matuyama Gauss reversal, consistently documented in cores ICDP Site 5011-1A and 1C (Haltia and Nowaczyk, 2013), occurred at $2.588 \mathrm{Ma}$, clearly within MIS 103 (Table 1, Fig. 6). Deino et al. (2006) provide an ${ }^{40} \mathrm{Ar} /{ }^{39}$ Ar-based age of $2.589 \pm 0.003$ Ma from two tephras, tightly bracketing the Matuyama Gauss reversal in the upper part of a diatomite of the fluvio-lacustrine sediments in the Chemeron Basin, Central Kenya Rift, Afrika. This would be in excellent agreement to our result. However, Deino et al. (2006) tune their radiometrically obtained age to an astronomically polarity timescale and shift this age to $2.610 \mathrm{Ma}$. This is close to the age of $2.608 \mathrm{Ma}$, given by Lisiecki and Raymo (2005). But, this would place the Matuyama Gauss reversal into MIS 104, a cold interval. This contradicts our stratigraphic results that only allow placement of the Matuyama Gauss reversal into the middle MIS 103 (Table 1, Fig. 6) (i.e. within a warm interval). This is also in agreement with findings by Prokopenko and Khursevich (2010) from Lake Baikal Site BDP-96. Thus, the Matuyama Gauss reversal at ICDP Site 5011-1, is definitely not recorded in MIS 104, but in MIS 103 at $2.588 \mathrm{Ma}$. The younger age of $2.581 \mathrm{Ma}$ for this major reversal, given by Ogg and Smith (2004), places the Matuyama Gauss reversal into the late MIS 103 which also does not fit to results from Lake El'gygytgyn.

The reversed Matuyama chron is mainly interrupted by the prominent Olduvai and Jaramillo normal polarity subchrons, clearly expressed in the ICDP Site 5011-1 record. Besides these, there are three further, much shorter intervals of normal polarity, not listed in Lisiecki and Raymo (2005): the Réunion subchron (Chamalaun and McDougall, 1966; McDougall and Watkins, 1973), an Olduvai precursor (Channell et al., 2003), and the Cobb Mountain subchron (Mankinen et al., 1978). The ICDP Site 5011-1 derived age range for the Réunion subchron of $2.1216-2.1384 \mathrm{Ma}$ is in good agreement with the GPTSs (Table 1) and radiometric dating results of $2.14 \pm 0.03 \mathrm{Ma}$ by Baksi et al. (1993), $2.137 \pm 0.016 \mathrm{Ma}$ by Singer et al. (2004), or $2.15 \pm 0.02 \mathrm{Ma}$ by Quidelleur et al. (2010). The results are also consistent with magnetostratigraphic data from North Atlantic ODP Site 981 (Feni Drift; Channell et al., 2003, Fig. 3), placing the Réunion subchron into MIS 80 and 81 (see Supplement). Magnetostratigraphic results from ICDP Site 5011-1 give an age range for the Olduvai precursor of 1.9782 to $1.9815 \mathrm{Ma}$ (MIS 75, see Supplement). It is consistently documented in cores ICDP Site 5011-1A and 1B (Haltia and Nowaczyk, 2013). Evidence for this more excursional feature, nearly reaching a full normal polarity prior to the Olduvai normal polarity subchron, comes from sediments in the North Atlantic (Channell et al., 2003). In the ICDP Site 5011-1 record the Cobb Mountain subchron is covering the time interval from 1.1858 to $1.1938 \mathrm{Ma}$. This is equivalent to late MIS 34 and early MIS 35 (see Supplement), similar to findings from the North Atlantic at IODP Site U1308 by Channell et al. (2008). The obtained age range is also in broad agreement 
with the GPTS (Table 1). Cores ICDP Site 5011-1A and 1B both show evidence for a short intra-Jaramillo excursion reaching reversed inclinations (Haltia and Nowaczyk, 2013). According to Channell et al. (2002), this short excursion occurred during MIS 30, a cold interval. Stratigraphic data from Lake El'gygytgyn, in contrast, only allows placing it into the younger warm interval of MIS 29 (Fig. 6) between 1.0142 and $1.0192 \mathrm{Ma}$ with a duration of $5000 \mathrm{yr}$. A late Jaramillo reversed excursion was also found in Chinese loess (Guo et al., 2002).

Evidence for geomagnetic excursions during the Bruhnes chron (see e.g. Laj and Channel, 2007 for a review) is completely missing in Lake El'gygytgyn sediments. The main reason might be the comparatively low sedimentation rates. Shallow inclinations in the younger Brunhes chron sediments are mostly related to slightly disturbed core intervals from pilot core Lz1024.

\subsection{Limnologic and climatic implications}

Figure 10 illustrates the response of Lake El'gygytgyn sediments to climate variability throughout the past $3.6 \mathrm{Ma}$ in more detail. The records of biogenic silica (FTIRS estimation), representing bioproductivity in the upper water layers of the lake, and TOC, representing mostly the efficiency of preservation of organic matter at the lake floor, are shown in Fig. 10a. The data is plotted in a way that both curves are superimposed in prominent anoxic intervals where a nearly complete preservation of organic matter is assumed, such as the glacial maxima of MIS $2(\sim 24 \mathrm{ka})$, MIS $4(\sim 65 \mathrm{ka})$, subglacial MIS $5 \mathrm{~b}(\sim 110 \mathrm{ka})$, and several intervals of MIS 6 $(\sim 135 \mathrm{ka}, \sim 160 \mathrm{ka}, \sim 180 \mathrm{ka})$. Otherwise, TOC values plot below the curve of biogenic silica, indicating a partial degradation of organic matter at the lake floor in the order of about 60 to $80 \%$ (green area between both curves). This is in agreement with earlier findings from Lake El'gygytgyn pilot core PG1351 (Nowaczyk et al., 2007), using biogenic silica concentrations measured by wet digestion techniques, rather than estimates based on FTIRS, as it was done for ICDP Site 5011-1 core material. Thus, in Lake El'gygytgyn sediments, the amount of TOC, in general, does not represent the primary bioproduction.

Records of Ti content (XRF counts), taken as a proxy of lithogenic input from the catchment, and magnetic susceptibility (MS), representing preservation of magnetic particles during phases of oxygenated bottom waters, are shown in Fig. 10b. Curves were plotted in a way that MS superimposes $\mathrm{Ti}$ in time intervals when best preservation of magnetic particles can be assumed during dominating oxic conditions at the lake floor. However, in most cases the MS curve plots below the Ti curve, indicating far-reaching dissolution of up to $95 \%$ of the magnetic fraction. There is even an anti-correlation between Ti content and magnetic susceptibility visible during longer sequences within the El'gygytgyn sedimentary record. Thus, magnetic susceptibility is anything but a proxy
Table 3. Positions and ages of tephra layers identified in Lake El'gygytgyn sediments. Core labels indicate: 1 - PG1351, 2 Lz1024, A - 5011-1A, B - 5011-1B, C - 5011-1C.

\begin{tabular}{lllr}
\hline Core & Index & 5011-1 composite depth (m) & Age (ka) \\
\hline 1, 2 & 0 & $2.54-2.55$ & 58 \\
1, 2, A, B & 1 & $7.88-7.89$ & 177 \\
A, B & 2 & $27.52-27.52$ & 674 \\
A, B & 3 & $36.41-36.47$ & 918 \\
A, B & 4 & $60.79-60.80$ & 1411 \\
A, B & 5 & $62.04-62.08$ & 1434 \\
A, B & 6 & $79.25-79.26$ & 1775 \\
A, B, C & 7 & $104.93-105.00$ & 2225 \\
\hline
\end{tabular}

for the input of lithogenic material, although magnetic particles were very likely derived from the catchment inside the El'gygytgyn crater, bearing highly magnetic volcanic rocks (Haltia and Nowaczyk, 2013). The massive loss of magnetic particles of up to $95 \%$ still allowed a clear detection of geomagnetic reversals (Haltia and Nowaczyk, 2013), but it definitely excludes a reliable estimation of relative geomagnetic palaeointensity variations (Nowaczyk et al., 2002, 2007). This is a major deficit of the El'gygytgyn sedimentary record, because correlation of palaeointensity variations to reference records, such as the PISO1500 stack (Channell et al., 2009) or the EPAPIS-3000 stack (Yamazaki and Oda, 2005, and further references therein), could have provided further geomagnetic tie points between the major reversals. This could have significantly substantiated the age model mainly derived from tuning Lake El'gygytgyn sedimentary climate proxies to the LR04 stack (Lisiecki and Raymo, 2005) and the Northern Hemisphere cumulative summer insolation, according to orbital solutions by Laskar et al. (2004). On the other hand, only the strict link between alternating redox conditions, leading to the alternating dissolution/preservation effects described above, and insolation variations enabled the definition of many tie points in the age model for ICDP Site 5011-1. Figure 10b also shows a clear anti-correlation between Ti and the LR04 stack. This indicates a dilution of the lithogenic fraction by biogenic components being larger (smaller) during warm (cold) phases. A good proxy for the varying ratio of bioproductivity, in Lake El'gygytgyn mostly biogenic (bio) silica from diatoms, to lithogenic (litho) input is the Si / Ti ratio (Melles et al., 2012; Wennrich et al., 2013), here obtained in high-resolution from XRF-scanning (Fig. 10c). Actually this ratio is $\left(\mathrm{Si}_{\text {bio }}+\mathrm{Si}_{\text {litho }}\right) / \mathrm{Ti}_{\text {litho }}$. Thus, when $\mathrm{Si}_{\text {bio }}$ approximates zero the $\mathrm{Si} / \mathrm{Ti}$ ratio approximates a certain value, depending on the average composition of the catchment rocks. The pure $(\mathrm{Si} / \mathrm{Ti})_{\text {litho }}$ ratio might also change due to an increased (decreased) chemical alteration under anoxic (oxic) condition in cold (warm) phases at the lake floor (Minyuk et al., 2007). Nevertheless, the modulation of the $\mathrm{Si} / \mathrm{Ti}$ ratio is obviously dominated by its varying biogenic contribution since the $\mathrm{Si} / \mathrm{Ti}$ ratio resembles 

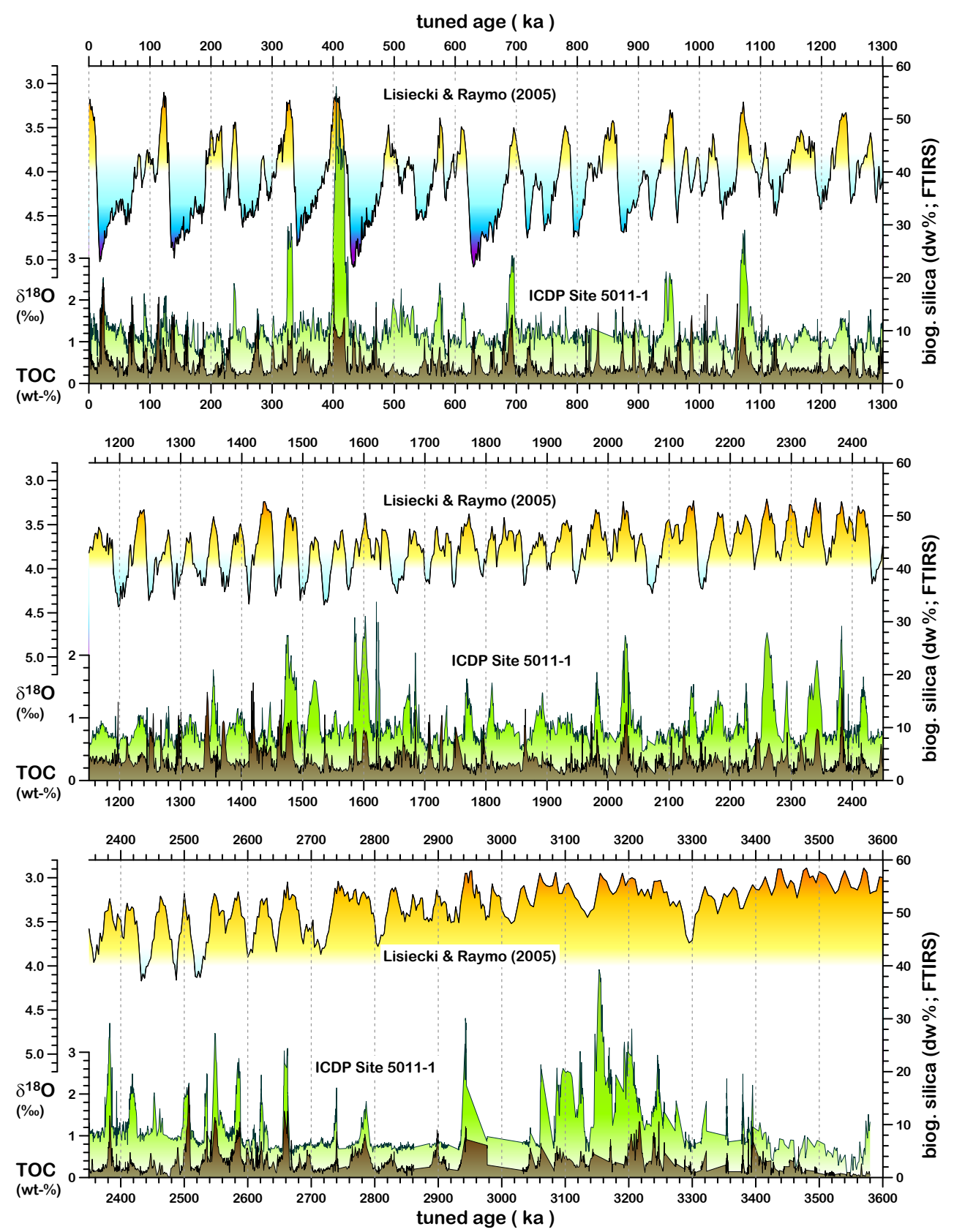

Fig. 10. Response of Lake El'gygytgyn (ICDP Site 5011-1) to climate variability as represented by the marine oxygen isotope $\left(\delta^{18} \mathrm{O}\right)$ stack LR04 (Lisiecki and Raymo, 2005): Time series of (a) biogenic silica (FTIRS estimation), representing bioproductivity in the upper water layers of the lake, and total organic carbon (TOC), representing preservation of organic matter at the lake floor during phases of anoxic bottom waters, (b) Ti content (XRF counts), taken as a proxy of lithogenic input from the catchment, and magnetic susceptibility (MS), representing preservation of magnetic particles during phases of oxygenated bottom waters, (c) hue angle (colour) and $\mathrm{Si} / \mathrm{Ti}$ ratio, both following global climate cycles. Curves in (a) and (b) were plotted in a way that TOC (MS) superimposes biogenic silica (Ti) in time intervals when best preservation of organic matter (magnetic particles) can be assumed during anoxic (oxic) conditions at the lake floor. Where the TOC curve lies below the biogenic silica curve in (a), partial degradation (60 to 80\%) of organic matter is indicated (green area between both curves). Where the MS curve lies below the Ti curve in (b), fairly massive dissolution (up to $95 \%$ ) of the magnetic fraction in the sediments is indicated (grey area between both curves). For further explanation see discussion in the text. 

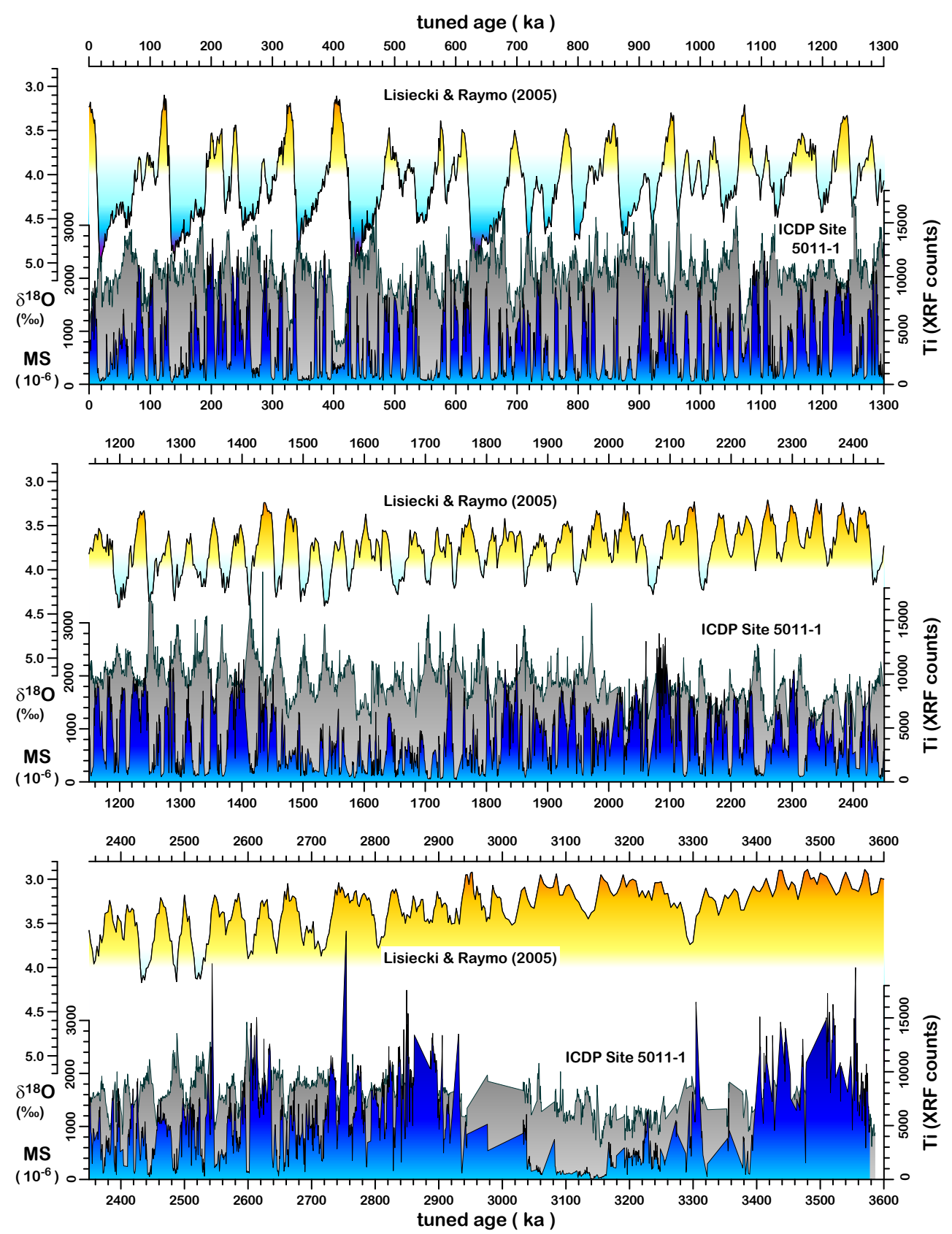

Fig. 10. Continued.

strongly the morphology of the FTIRS-BSi curve representing only biogenic silica (Fig. 6). The variations in $\mathrm{Si} / \mathrm{Ti}$ ratio are also parallelled by changes in colour (hue angle) from yellowish brown $\left(80^{\circ}\right)$ to greenish grey $\left(140^{\circ}\right)$, also shown in Fig. 10c. According to an initial study on the time interval from MIS 8 to 12 (Wei et al., 2013), combining colour spectral data with mineralogical data from X-ray diffraction (XRD), colour changes mainly reflect physical weathering processes, with some additional chemical weathering, reflecting wet dry cyclicity. Thus, the hue angle turned out to be a very helpful parameter for tuning the ICDP Site 5011-1 sedimentary sequence and more detailed analyses of the full spectral colour information, from which the hue angle was derived, might give further information in the future. The percentages of tree $\&$ shrub pollen also vary in concert with variation in biogenic silica, $\mathrm{Si} / \mathrm{Ti}$ ratio, colour (hue), and grain size (Fig. 6), but these aspects exceed the focus of this paper. Major environmental implications of the pollen record is published in Melles et al. (2012) and Brigham-Grette et al. (2013). 


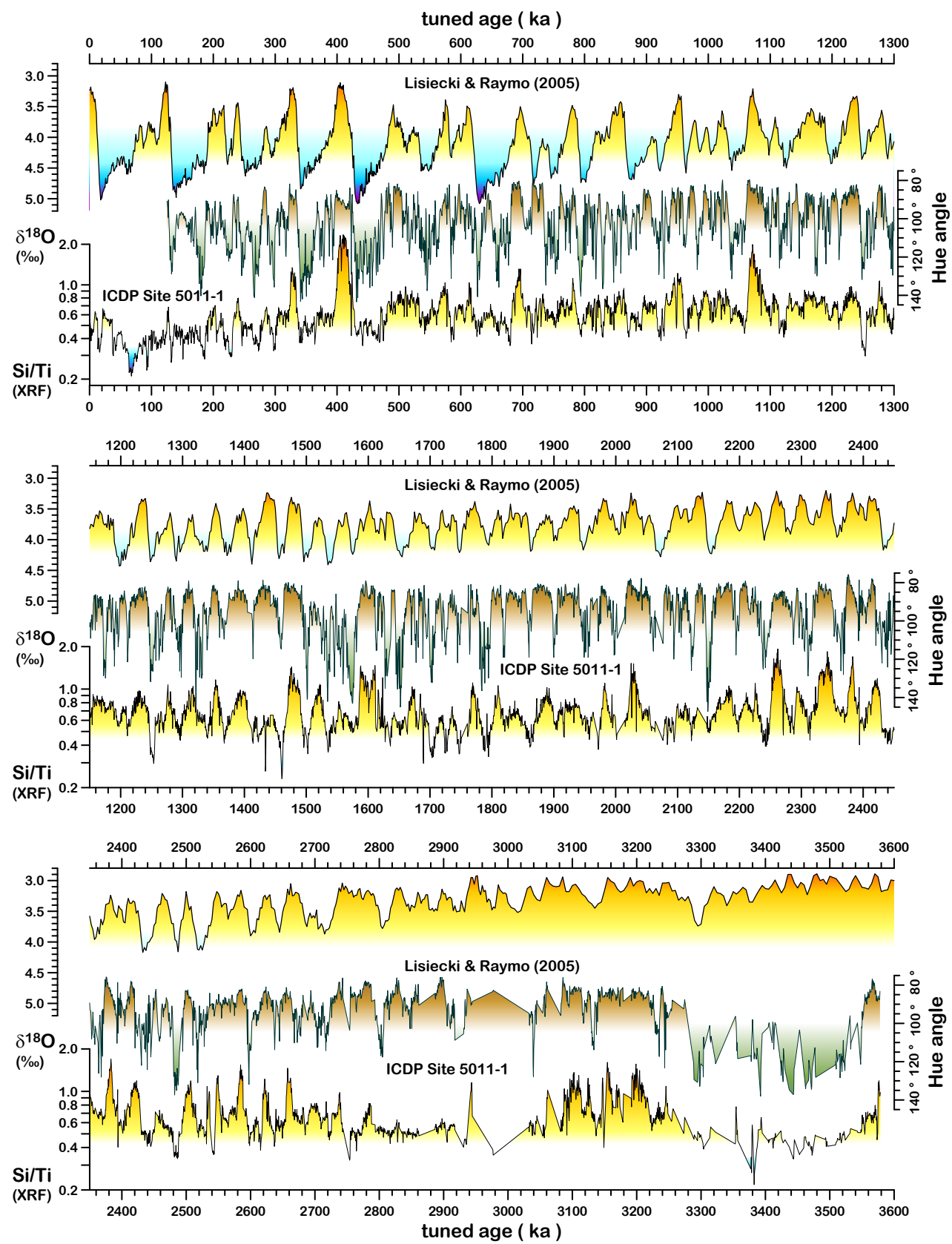

Fig. 10. Continued.

Data from Lake El'gygytgyn have been subjected to some wavelet time-series analysis (e.g. Torrence and Compo, 1997; Kumar and Foufoula-Georgiou, 1997). Wavelet analysis is the preferred method for a time-dependent frequency analysis, that is, in cases when non-stationary frequencies have to be confirmed in a time series. Actually it is a crosscorrelation of a time series with a whole set of single base frequencies which are multiplied with a certain taper function (e.g. a Gaussian curve). Concerning the wavelet, the multiplication in the time domain is equivalent with a convolution of the spectral peak of the base frequency with the Fourier transform of the taper function in the frequency domain, which is a Gaussian curve in the case of a Gaussian curve (see Torrence and Compo, 1997). Thus, a wavelet is always sensitive to a whole frequency band centred by the base frequency of the wavelet. For analyses of Lake El'gygytgyn sediments a Morlet wavelet with a base frequency of 6 and a scale of 200 a was used (see Torrence and Compo, 1997), applying the PAST software (Hammer et al., 2001), Version 2.17. Prior to analyses data sets were re-sampled every $200 \mathrm{a}$. 

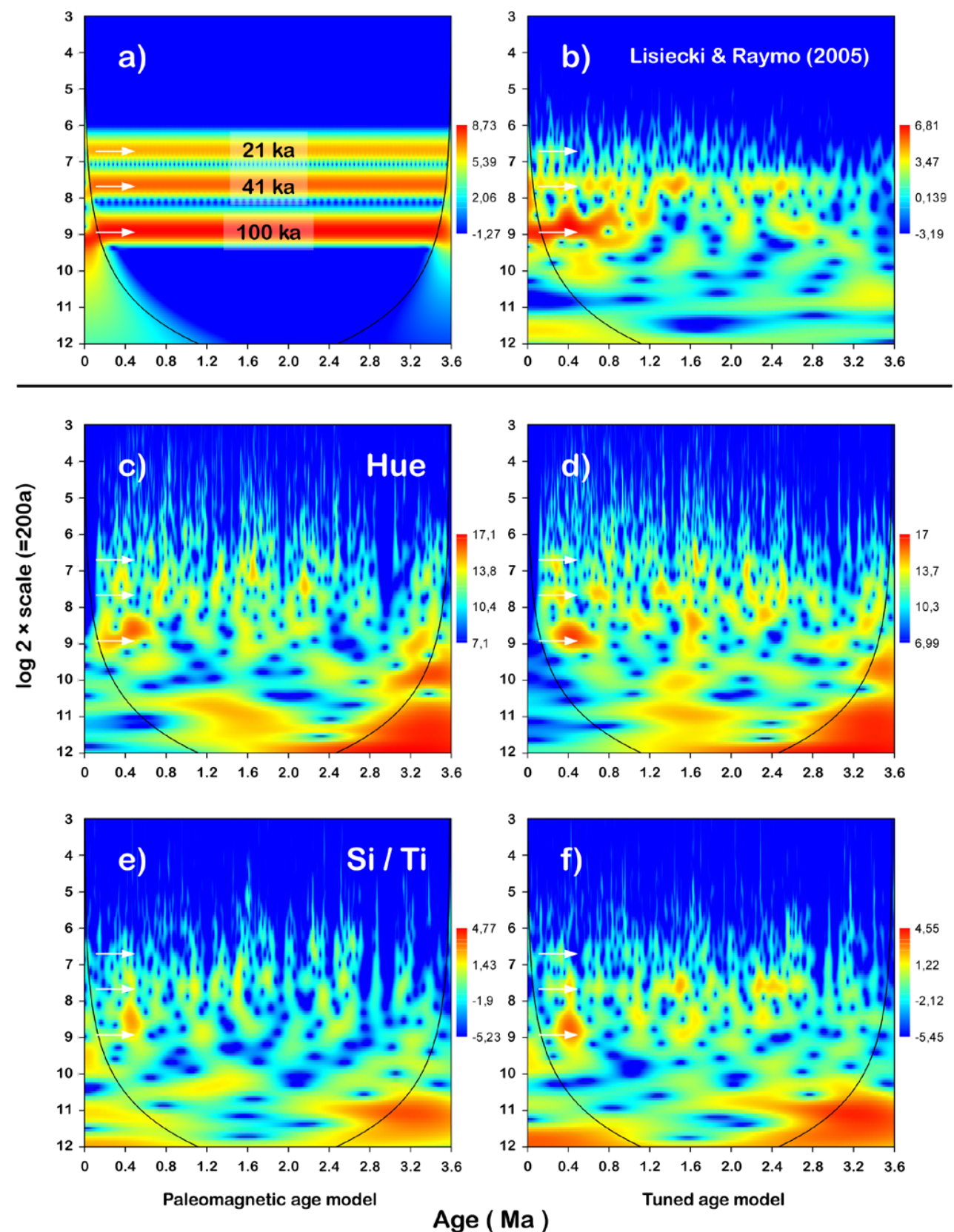

Fig. 11. Wavelet analyses using a Morlet wavelet with a base frequency of 6 and a scale of 200 a performed on some stratigraphic properties from Lake El'gygytgyn used for tuning: (a) persistent mono-frequency sine waves with periods of $21 \mathrm{ka}$ (precession, at 6.7145), 41 ka (obliquity, at 7.6795), and $100 \mathrm{ka}$ (eccentricity, at 8.9658) for reference, (b) the marine oxygen isotope stack by Lisiecki and Raymo (2005) that was used as one tuning reference curve, times series of (c) hue angle of sediment colour and (e) Si / Ti ratio from XRF scanning solely based on magnetostratigraphic dating and the same with fine-tuned age model (d) and (f). White arrows always mark the positions of the major astronomical periods shown in (a).

For illustration of the (limited) frequency resolution Fig. 11a shows the result from a superposition of three pure sine waves with periods of $21 \mathrm{ka}$ (precession of earth's rotation axis), $41 \mathrm{ka}$ (obliquity variations of earth's rotation axis), and $100 \mathrm{ka}$ (eccentricity variations of earth's orbit), constantly persisting from 0 to $3.6 \mathrm{Ma}$. According to the theory of wavelet analysis, they are not represented by a single spectral line but a whole frequency band. The wavelet analysis of the LR04 stack in Fig. $11 \mathrm{~b}$ reveals that the 100 ka cycle has been persisting only during the past about $800 \mathrm{ka}$. The $41 \mathrm{ka}$ cycle can be clearly traced back to about $2.5 \mathrm{Ma}$. Figure $11 \mathrm{c}$ and $\mathrm{d}$ (11e and $\mathrm{f}$ ) show the results from the hue ( $\mathrm{Si} / \mathrm{Ti}$ ratio) 
on the basis of the palaeomagnetic age model only, and after fine-tuning to both the LR04 stack and the Northern Hemisphere summer insolation. The three astronomical periods shown in Fig. 11a, also indicated by white arrows, are less visible as in the LR04 stack, but nevertheless, a certain improvement can be seen, especially the $100 \mathrm{ka}$ and the $41 \mathrm{ka}$ frequency band. Finally, when considering Fig. 7, the pure palaeomagnetic age model already gave a fairly good estimate for the final fine-tuned age model. Thus, the deviations between the results from wavelet analysis in Fig. 11c (11e) and d (11f) cannot be large.

\subsection{Tephra layers}

Up to now, a total of eight tephra layers have been identified in Lake El'gygytgyn sediments. Currently, radiometric ages are not yet available. However, based on multi-proxy tuning of the sediments they are embedded in, tephra ages could be determined by chrono-stratigraphic means of this study. Their positions in composite depth and respective ages are listed in Table 3. Tephra 1 (177 ka) is described in some detail by Ponomareva et al. (2013). Large volcanic eruptions on Kamchatka listed by Bindemann et al. (2010) are potential sources of the tephras. Geochemical fingerprints worked out by van den Bogaard et al. (2013) shows that most of the tephras can be linked to the volcanic activity on Kamchatka. Only tephra 6 (1775 ka) should be related to the Aleutian volcanic arc. Thus, the origins of the tephras is sited more than $1000 \mathrm{~km}$ away from Lake El'gygytgyn, indicating that the observed tephras are marker layers of regional importance.

\section{Conclusions}

Despite the presence of more than 300 turbidites, mass movements of up to $1.2 \mathrm{~m}$ thickness (Sauerbrey et al., 2013), and poor core recovery in the lower section, a fairly detailed age model could be achieved for the about $320 \mathrm{~m}$ thick ICDP Site 5011-1 sedimentary composite record from Lake El'gygytgyn, Far Eastern Russian Arctic, covering the past 3.6 Ma. Reference ages of 14 reversals of the geomagnetic field, documented in the sediments, are provided by the timescales of Lisiecki and Raymo (2005) and Ogg and Smith (2004), respectively, showing slightly deviating ages for some of the reversals (Table 1). Within that range, reversal ages derived from chronostratigraphic analyses of Lake El'gygytgyn sediments are in a general agreement with these timescales. Thus, we suggest an age of $2.588 \mathrm{Ma}$ for the Matuyama Gauss reversal. For the Réunion subchron a duration extending from 2.1384 to $2.1216 \mathrm{Ma}$ could be derived. Our study confirms the existence of a short-term Olduvai precursor from 1.9815 to $1.9782 \mathrm{Ma}$, reaching full normal polarity, also documented in North Atlantic sediments (Channell et al., 2003). In ICDP Site 5011-1 sediments, the Cobb Mountain subchron is covering the time interval from
1.1938 to $1.1858 \mathrm{Ma}$. Our data also give evidence for an intra-Jaramillo excursion lasting from 1.0192 to $1.0142 \mathrm{Ma}$ in MIS 29, which is younger than ages derived from other studies, placing it in MIS 30 (Channell et al., 2002). Despite recording of such short-term geomagnetic field features during the Matuyama chron no evidence for excursions within the Brunhes chron was found in Lake El'gygytgyn sediments. Repeatedly occurring perversive magnetite dissolution throughout the whole Pleistocene inhibited a reconstruction of geomagnetic palaeointensity variations. Nevertheless, in addition to the polarity stratigraphy, a synchronous tuning of 9 stratigraphic parameters to the LR04 marine oxygen isotope stack (Lisiecki and Raymo, 2005) and to the Northern Hemisphere cumulative summer insolation (May to August), according to orbital solutions by Laskar et al. (2004), respectively, led to a significant refinement of the age model by the definition of a total of about 600 tie points. The age model has some uncertainties towards the base of the (Pliocene) sediments between 2.94 and $3.54 \mathrm{Ma}$, mainly due to low sediment recovery during drilling. Here, pronounced variation in the percentages of tree pollen provided major clues for age assignments. Estimated sedimentation rates are in the range of 4 to $5 \mathrm{~cm} \mathrm{ka}^{-1}$ for the past about $3.3 \mathrm{Ma}$, whereas the first $0.3 \mathrm{Ma}$ after the impact that created the El'gygytgyn crater are characterised by about ten-fold higher sedimentation rates. This study also provides orbitally tuned ages for a total of eight remote tephras deposited in Lake El'gygytgyn which can act as marker layers in future studies.

Acknowledgements. Funding for this research was provided by the International Continental Scientific Drilling Program (ICDP), the US National Science Foundation (NSF), the German Federal Ministry of Education and Research (BMBF), Alfred Wegener Institute (AWI) and Helmholtz Centre Potsdam (GFZ), the Russian Academy of Sciences Far East Branch (RAS FEB), the Russian Foundation for Basic Research (RFBR), and the Austrian Federal Ministry of Science and Research (BMWF). The Russian GLAD 800 drilling system was developed and operated by DOSECC Inc., the down hole logging was performed by the ICDP-OSG, and LacCore, at the University of Minnesota, handled core curation. We like to thank all the participants of the expedition to Lake El'gygytgyn from January to May 2009 for their engagement during recovery of the ICDP Site 5011-1 cores. Numerous students helped during laboratory work. Wavelet analyses were performed using the PAST software package, Vers. 2.17, provided by Øyvind Hammer, Natural History Museum, University of Oslo (http://folk.uio.no/ohammer/past/index.html). This study was partly financed by BMBF grant no. 03G0642C - "Geochronology of the sediments in the El'gygytgyn crater".

The service charges for this open access publication have been covered by a Research Centre of the Helmholtz Association.

Edited by: B. Wagner 


\section{References}

Andreev, A. A., Tarasov, P. E., Wennrich, V., Raschke, E., Herzschuh, U., Nowaczyk, N. R., Brigham-Grette, J., and Melles, M.: Late Pliocene and early Pleistocene environments of the north-eastern Russian Arctic inferred from the Lake El'gygytgyn pollen record, Clim. Past Discuss., 9, 4599-4653, doi:10.5194/cpd-9-4599-2013, 2013.

Baksi, A. K., Hoffman, K. A., and McWilliams, M.: Testing the accuracy of the geomagnetic polarity time-scale (GPTS) at 2$5 \mathrm{Ma}$, utilizing ${ }^{40} \mathrm{Ar} /{ }^{39} \mathrm{Ar}$ incremental heating data on wholerock basalts, Earth Planet. Sc. lett., 118, 135-144, 1993.

Bindemann, I. N., Leonov, V. L., Izbekov, P. E., Ponomareva, V. V., Watts, K. E., Shipley, N. K., Perepelov, A. B., Bazanova, L. I., Jicha, B. R., Singer, B. S, Schmitt, A. K., Portnyagin, M. V., and Chen, C. H.: Large-volume silicic volcanism in Kamchatka: Ar-Ar, and U-Pb ages, isotopic, and geochemical characteristics of major pre-Holocene caldera-forming eruptions, Bull. Volc. Geotherm. Res., 189, 57-80, 2010.

Blaauw, M.: Out of tune: the dangers of aligning proxy archives, Quaternary Sci. Rev., 36, 38-49, 2012.

Bokhorst, M. P. and Vandenberghe, J.: Validation of wiggle matching using a multi-proxy approach and its palaeoclimatic significance, J. Quaternary Sci., 24, 937-947, 2009.

Brigham-Grette, J., Melles, M., Minyuk, P., Andreev, A., Tarasov, P., DeConto, R, Koenig, S., Nowaczyk, N., Wennrich, V., Rosén, P., Haltia, E., Cook, T., Gebhard, C., Meyer-Jacob, C., Snyder, J. and Herzschuh, U.: Pliocene warmth, polar amplification, and stepped Pleistocene cooling recorded in NE Arctic Russia, Science express, 340, 1421-1427, doi:10.1126/science.1233137, 2013.

Cande, S. C. and Kent, D. V.: Revised calibration of the geomagnetic polarity timescale for the late Cretaceous and Cenozoic, J. Geophys. Res., 100, 6093-6095, 1995.

Chamalaun, F. H. and McDougall, I.: Dating geomagnetic polarity epoches in Réunion, Nature, 210, 1212-1214, 1966.

Channell, J. E. T., Mazaud, A., Sullivan, P., Turner, S., and Raymo, M. E.: Geomagnetic excursions and paleointensities in the Matuyama Chron at Ocean Drilling Porgram Sites 983 and 984 (Iceland Basin), J. Geophys. Res., 107, EPM 1.1-EPM 1.14, doi:10.1029/2001JB000491, 2002.

Channell, J. E. T., Labs, J., and Raymo, M. E.: The Réunion subchronozone at ODP site 981 (Feni Drift, North Atlantic), Earth Planet. Sc. Lett., 215, 1-12, 2003.

Channell, J. E. T., Hodell, D. A., Xuan, C., Mazaud, A., and Stoner, J. S.: Age calibrated paleointensity for the last $1.5 \mathrm{Myr}$ at ODP Site U1308 (North Atlantic), Earth Planet. Sc. Lett., 274, 59-71, 2008.

Channel, J. E. T., Xuan, C., and Hodell, D. A.: Stacking paleointensity and oxygen isotope data for the last $1.5 \mathrm{Myr}$ (PISO-1500), Earth Planet. Sc. Lett., 283, 14-23, 2009.

Cherapanova, M. V., Snyder, J. A., and Brigham-Grette, J.: Diatom stratigraphy of the last $250 \mathrm{ka}$ at Lake El'gygytgyn, northeast Siberia, J. Paleolimnol., 37, 155-162, 2007.

Deino, A. L., Kingston, J. D., Glen, J. M., Edgar, R. K., and Hill, A.: Precessional forcing of lacustrine sedimentation in the late Cenozoic Chemeron Basin, Central Kenya Rift, and calibration of the Gauss/Matuyama boundary, Earth Planet. Sc. Lett., 247, 41-60, 2006.
Francke, A., Wennrich, V., Sauerbrey, M., Juschus, O., Melles, M., and Brigham-Grette, J.: Multivariate statistic and time series analyses of grain-size data in Quaternary sediments of Lake El'gygytgyn, NE Russia, Clim. Past Discuss., 9, 217-244, doi:10.5194/cpd-9-217-2013, 2013.

Frank, U., Nowaczyk, N. R., Minyuk, P., Vogel, H., Rosén, P., and Melles, M.: A $350 \mathrm{ka}$ record of climate change from Lake El'gygytgyn, Far East Russian Arctic: refining the pattern of climate modes by means of cluster analysis, Clim. Past, 9, 15591569, doi:10.5194/cp-9-1559-2013, 2013.

Guo, B., Zhu, R., Florindo, F., Ding, Z., and Sun, J. A.: A short, reverse polarity interval within the Jaramillo subchron: Evidence from the Jingbian section, northern China Loess plateau, J. Geophys. Res., 107, 10029-10040, 2002.

Gurov, E. P. and Koeberl, C.: Shocked rocks and impact glasses from the El'gygytgyn impact structure, Russia, Meteorit. Planet. Sci., 39, 1495-1508, 2004.

Haltia, E. M. and Nowaczyk, N. R.: Magnetostratigraphy of sediments from Lake El'gygytgyn ICDP Site 5011-1: paleomagnetic age constraints for the longest paleoclimate record from the continental Arctic, Clim. Past Discuss., 9, 5077-5122, doi:10.5194/cpd-9-5077-2013, 2013.

Hammer, Ø., Harper, D. A. T., and Ryan, P. D.: PAST: Paleontological Statistics Software Package for Education and Data Analysis, Palaeontol. Electron., 4, 9 pp., 2001.

Juschus, O., Preusser, F., Melles, M., and Radtke, U.: Applying SAR-IRSL methodology for dating fine-grained sediments from Lake El'gygytgyn, north-eastern Siberia, Quat. Geochronol., 2, 187-194, 2007.

Kirschvink, J. L.: The least-squares line and plane and the analysis of palaeomagnetic data, Geophys. J. Roy. Astr. S., 62, 699-718, 1980.

Kelley, S. P., Spicer, R. A., and Herman, A. B.: New ${ }^{40} \mathrm{Ar} /{ }^{39} \mathrm{Ar}$ dates for Cretaceous Chauna Group tephra, north-eastern Russia, and their implications for the geologic history and floral evolution of the North Pacific region, Cret. Res., 20, 97-106, 1999.

Kumar, P. and Foufoula-Georgiou, E.: Wavelet analysis for geophysical applications, Rev. Geophys., 35, 385-412, 1997.

Laj, C. and Channell, J. E. T.: Geomagnetic excursions, in: Treatise on Geophysics, Geomagnetism, edited by: Schubert, G., Bercovici, D., Dziewonski, A., Herring, T., Kanamori, H., Kono, M., Olson, P. L., Price, G. D., Romanowicz, B., Spohn, T., Stevenson, D., and Watts, A. B., Vol. 5. Elsevier, B.V., Amsterdam, 373-416, 2007.

Laskar, J., Robutel, F., and Boudin, F.: Orbital, precessional, and insolation quantities for the Earth from $-20 \mathrm{Myr}$ to $+10 \mathrm{Myr}$, Astron. Astrophys., 270, 522-533, 1993.

Laskar, J., Robutel, P., Joutel, F., Gastineau, M., Correia, A. C. M., and Levrard, B.: A long-term numerical solution for the insolation quantities of the Earth, Astron. Astrophys., 428, 261-285, 2004.

Layer, P. W.: Argon-40/Argon-39 age of the El'gygytgyn impact event, Chukotka, Russia, Meteorit. Planet. Sci., 35, 591-599, 2000.

Lisiecki, L. E. and Raymo, M. E.: A Pliocene-Pleistocene stack of 57 globally distributed benthic $\delta^{18} \mathrm{O}$ records, Paleoceanography, 20, PA1003, doi:10.1029/2004PA001071, 2005. 
Lisiecki, L. E. and Raymo, M. E.: Diachronous benthic $\delta^{18} \mathrm{O}$ responses during late Pleistocene terminations, Paleoceanography, 24, PA3210, doi:10.1029/2009PA001732, 2009.

Lourens, L. J., Antonarakou, A., Hilgen, F. J., Van Hoof, A. A. M., Vergnaud-Grazzini, C., and Zachariasse, W. J.: Evaluation of the Plio-Pleistocene astronomical timescale, Paleoceanography, 11, 391-413, 1996.

Lozhkin, A. V. and Anderson, P. M.: Vegetation responses to interglacial warming in the Arctic: examples from Lake El'gygytgyn, Far East Russian Arctic, Clim. Past, 9, 1211-1219, doi:10.5194/cp-9-1211-2013, 2013.

Lozhkin, A. V., Anderson, P. M., Matrosova, T. V., and Minyuk, P. S.: The pollen record from El'gygytgyn Lake: implications for vegetation and climate histories of northern Chukotka since the late middle Pleistocene, J. Paleolimnol., 37, 135-153, 2007.

Maharaj, D., Elbra, T., and Pesonen, L. J.: Physical properties of the El'gygytgyn impact structure, NE Russia, Meteorit. Planet. Sci., 48, 1130-1142, 2013.

Mankinen, E. A., Donelly, J. M., and Grommé, C. S.: Geomagnetic polarity event recorded at 1.1 m.y. B.P. on Cobb Mountain, Clear Lake volcanic field, California, Geology, 6, 653-656, 1978.

McDougall, I. and Watkins, N. D.:. Age and duration of the Réunion geomagnetic polarity event, Earth Planet. Sc. Lett., 19, 443-452, 1973.

Melles, M., Brigham-Grette, J., Glushkova, O. Y., Minyuk, P. S., Nowaczyk, N. R., and Hubberten, H.-W.: Sedimentary geochemistry of core PG1351 from Lake El'gygytgyn - a sensitive record of climate variability in the East Siberian Arctic during the past three glacial-interglacial cycles, J. Paleolimnol., 37, 89-104, 2007.

Melles, M., Brigham-Grette, J., Minyuk, P., Koeberl, C., Andreev, A., Cook, T., Fedorov, G., Gebhardt, C., Haltia-Hovi, E., Kukkonen, M., Nowaczyk, N., Schwamborn, G., Wennrich, V., and the El'gygytgyn Scientific Drilling Project - conquering Arctic challenges through continental drilling, Sci. Drilling, 11, 29-40, 2011.

Melles, M., Brigham-Grette, J., Minyik, P. S., Nowaczyk, N. R., Wennrich, V., DeConto, R. M., Anderson, P. M., Andreev, A. A., Coletti, A., Cook, T. L., Haltia-Hovi, E., Kukkonen, M., Lozhkin, A. V., Rosén, P., Tarasov, P., Vogel, H., and Wagner, B.: 2.8 Million years of Arctic climate change from Lake El'gygytgyn, NE Russia, Science, 337, 315-320, doi:10.1126/1222135, 2012.

Meyer-Jacob, C., Vogel, H., Melles, M., and Rosén, P.: Biogeochemical properties and diagenetic changes during the past 3.6 Ma recorded by FTIR spectroscopy in the sediment record of Lake El'gygytgyn, Far East Russian Arctic, Clim. Past Discuss., 9, 2489-2515, doi:10.5194/cpd-9-2489-2013, 2013.

Minyuk, P. S., Brigham-Grette, J., Melles, M., Borkhodoev, V. Y., and Glushkova, O. Y.: Inorganic geochemistry of El'gygytgyn Lake Sediments (northeastern Russia) as an indicator of paleoclimatic change for the last $250 \mathrm{kyr}$, J. Paleolimnol., 37, 123-133, 2007.

Murdock, K. J., Wilkie, K., and Brown, L. L.: Rock magnetic properties, magnetic susceptibility, and organic geochemistry comparison in core LZ1029-7 Lake El'gygytgyn, Russia Far East, Clim. Past, 9, 467-479, doi:10.5194/cp-9-467-2013, 2013.

Nolan, M. and Brigham-Grette, J.: Basic hydrology, limnology, and meteorology of modern Lake El'gygytgyn, Siberia, J. Paleolimnol., 37, 17-35, 2007.
Nowaczyk, N. R.: Logging of magnetic susceptibility, in: Tracking environmental change using lake sediments. Vol I: Basin analysis, coring, and chronological techniques, edited by: Last, W. M. and Smol, J. P., Kluwer Academic Publishers, Bortrecht, Netherlands, 155-170, 2001.

Nowaczyk, N. R., Minyuk, P., Melles, M., Brigham-Grette, J., Glushkova, O., Nolan, M., Lozhkin, A. V., Stetsenko, T. V., Anderson, P. M., and Forman, S. L.: Magnetostratigraphic results from impact crater Lake El'gygytgyn, northeastern Siberia: a $300 \mathrm{kyr}$ long high-resolution terrestrial palaeoclimatic record from the Arctic, Geophys. J. Int., 150, 109-126, 2002.

Nowaczyk, N. R., Melles, M., and Minyuk, P.: A revised age model for core PG1351 from Lake El'gygytgyn, Chukotka, based on magnetic susceptibility variations tuned to northern hemisphere insolation variations, J. Paleolimnol., 37, 65-76, 2007.

Ogg, J. G. and Smith, A. G.: The geomagnetic polarity time scale, in: Gradstein, F., Ogg, J., and Smith, A., A Geological Timescale 2004, Cambridge University Press, 63-86, 2004.

Ponomareva, V., Portnyagin, M., Derkachev, A., Juschus, O., Garbe-Schönberg, D., and Nürnberg, D.: Identification of a widespread Kamchatkan tephra: a middle Pleistocene tie-point between Arctic and pacific paleoclimatic records, Geophys. Res. Lett., 40, 3538-3543, doi:10.1002/grl.50645, 2013.

Prokopenko, A. A. and Khursevich, G. K.: Plio-Pleistocene transition in the continental record from Lake Baikal: Diatom biostratigraphy and age model, Quaternary Int., 219, 26-36, 2010.

Prokopenko, A. A., Hinnov, L. A., Williams, D. F., and Kuzmin, M. I.: Orbital forcing of continental climate during the Pleistocene: a complete astronomically tuned climatic record from Lake Baikal, SE Siberia, Quaternary Sci. Rev., 25, 3431-3457, 2006.

Quidelleur, X., Holt, J. W., Salvany, T., and Bouquerel, H.: New $\mathrm{K}-\mathrm{Ar}$ ages from La Montagne massif, Réunion Island (Indian Ocean), supporting two geomagnetic events in the time period 2.2-2.0 Ma, Geophys. J. Int., 182, 699-710, 2010.

Rosén, P., Vogel, H., Cunningham, L., Reuss, N., Conley, D. J., and Persson, P.: Fourier transform infrared spectroscopy, a new method for rapid determination of total organic and inorganic carbon and biogenic silica concentration in lake sediments, J. Paleolimnol., 43, 247-259, 2010.

Rosén, P., Vogel, H., Cunningham, L., Hahn, A., Hausmann, S., Pienitz, R., Zolitschka, B., Wagner, B., and Persson, P.: Universally applicable model for the quantitative determination of lake sediment composition using Fourier transform infrared spectroscopy, Environ. Sci. Technol., 45, 8858-8865, 2011.

Sauerbrey, M. A., Juschus, O., Gebhardt, A. C., Wennrich, V., Nowaczyk, N. R., and Melles, M.: Mass movement deposits in the 3.6 Ma sediment record of Lake El'gygytgyn, Far East Russian Arctic, Clim. Past, 9, 1949-1967, doi:10.5194/cp-9-19492013, 2013.

Singer, B. A., Brown, L. L., Rabassa, J. O., and Guillou, H.: ${ }^{40} \mathrm{Ar} /{ }^{39} \mathrm{Ar}$ chronology of Late Pliocene and Early Pleistocene geomagentic and glacial events in Southern Argentina, in: Channell, J. E. T., Kent, D. V., Lowrie, W., and Meert, J. G., Timescales of the Paleomagnetic Field, Geophys. Monograph Ser., 145, Amer. Geophys. Union, Washington, DC, 175-190, 2004.

Torrence, C. and Compo, G. P.: A practical guide to wavelet analysis, B. Am. Meteorol. Soc., 79, 61-78, 1997. 
van den Bogaard, C., Jensen, B. J. L., Pearce, N. J. G., Froese, D. G., Portnyagin, M. V., Ponomareva, V. V., Garbe-Schönberg, D., and Wennrich, V.: Volcanic ash layers in Lake El'gygytgyn: eight new regionally significant chronostratigraphic markers for western Beringia, Clim. Past Discuss., 9, 5977-6034, doi:10.5194/cpd-9-5977-2013, 2013.

Vogel, H., Rosén, P., Wagner, B., Melles, M., and Persson, P.: Fourier transform infrared spectroscopy, a new cost-effective tool for quantitative analysis of biogeochemical properties in long sediment records, J. Paleolimnol., 40, 689-702, 2008.

Vogel, H., Meyer-Jacob, C., Melles, M., Brigham-Grette, J., Andreev, A. A., Wennrich, V., Tarasov, P. E., and Rosén, P.: Detailed insight into Arctic climatic variability during MIS 11c at Lake El'gygytgyn, NE Russia, Clim. Past, 9, 1467-1479, doi:10.5194/cp-9-1467-2013, 2013.
Wei, J., Finkelstein, D., Brigham-Grette, J., Castaneda, I., and Nowaczyk, N.: Sediment color reflectance spectroscopy as a proxy for wet/dry cycles at Lake El'gygytgyn, Far East Russia, during marine isotope stages 8 to 12 , Sedimentology, in review, 2013.

Wennrich, V., Minyuk, P. S., Borkhodoev, V. Ya., Francke, A., Ritter, B., Nowaczyk, N., Sauerbrey, M. A., Brigham-Grette, J., and Melles, M.: Pliocene to Pleistocene climate and environmental history of Lake El'gygytgyn, Far East Russian Arctic, based on high-resolution inorganic geochemistry data, Clim. Past Discuss., 9, 5899-5940, doi:10.5194/cpd-9-5899-2013, 2013.

Yamazaki, T. and Oda, H.: A geomagnetic paleointensity stack between 0.8 and $3.0 \mathrm{Ma}$ from equatorial Pacific sediment cores, Geochem. Geophy. Geosys., 6, Q11H20, doi:10.1029/2005GC001001, 2005. 